Article

\title{
Assessment of the Usability and Accuracy of the Simplified One-Diode Models for Photovoltaic Modules
}

\author{
Vincenzo Franzitta, Aldo Orioli * and Alessandra Di Gangi \\ DEIM Dipartimento di Energia, Ingegneria dell'Informazione e Modelli Matematici, \\ Università degli Studi di Palermo, Viale delle Scienze Edificio 9, 90128 Palermo, Italy; \\ vincenzo.franzitta@unipa.it (V.F.); alessandradigangi@dream.unipa.it (A.D.G.) \\ * Correspondence: orioli@dream.unipa.it or aldo.orioli@unipa.it; Tel.: +39-091-23861905; Fax: +39-091-484425
}

Academic Editors: Senthilarasu Sundaram and Tapas Mallick

Received: 17 October 2016; Accepted: 25 November 2016; Published: 6 December 2016

\begin{abstract}
Models for photovoltaic (PV) cells and panels, based on the diode equivalent circuit, have been widely used because they are effective tools for system design. Many authors have presented simplified one-diode models whose three or four parameters are calculated using the data extracted from the datasheets issued by PV panel manufactures and adopting some simplifying hypotheses and numerical solving techniques. Sometimes it may be difficult to make a choice among so many models. To help researchers and designers working in the area of photovoltaic systems in selecting the model that is fit for purpose, a criterion for rating both the usability and accuracy of simplified one-diode models is proposed in this paper. The paper minutely describes the adopted hypotheses, analytical procedures and operative steps to calculate the parameters of the most famous simplified one-diode equivalent circuits. To test the achievable accuracy of the models, a comparison between the characteristics of some commercial PV modules issued by PV panel manufacturers and the calculated current-voltage $(I-V)$ curves, at constant solar irradiance and/or cell temperature, is carried out. The study shows that, even if different usability ratings and accuracies are observed, the simplified one-diode models can be considered very effective tools.
\end{abstract}

Keywords: photovoltaic modules; one-diode equivalent circuit; three-parameter model; four-parameter model; $I-V$ characteristics; solar energy

\section{Introduction}

A mathematical model used to simulate physical behaviours of PV modules needs a compromise between analytical complexity and achievable precision [1].

The one-diode model is a simplified version of the two-diode model proposed by Wolf [2] in order to represent the physical structure of a PV cell. As Wolf observed, the photocurrent in a PV cell is not generated by only one illuminated diode, but it is rather the global effect of the presence of a multitude of elementary flanked diodes that are uniformly distributed throughout the surface that separates the two slabs of the semiconductor junction. For this reason, a PV cell should be realistically approximated with a distributed constant electric circuit containing a multitude of elementary lumped components such as current generators, diodes and electrical resistances. Because such an equivalent circuit would be too complex to use, a simplified equivalent circuit was adopted. The circuit, which is depicted in Figure 1, contains only one pair of diodes with reverse saturation currents $I_{01}$ and $I_{02}$, a current generator and two resistors $R_{s}$ and $R_{s h}$, which take account of dissipative effects and parasitic currents within the PV panel. 


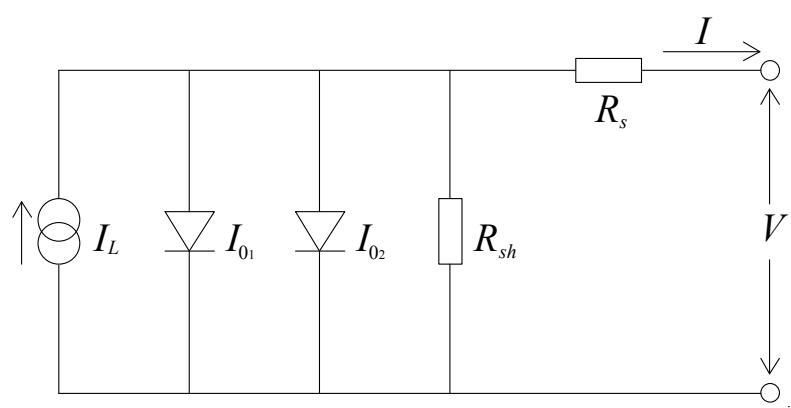

Figure 1. Two-diode equivalent circuit for a PV panel.

The second diode was added to consider the effect of the carrier recombination in the depletion region. The two-diode equivalent circuit of a PV module is described by the equation:

$$
I=I_{L}-I_{01}\left(e^{\frac{V+I R_{s}}{n_{1} T}}-1\right)-I_{02}\left(e^{\frac{V+I R_{s}}{n_{2} T}}-1\right)-\frac{V+I R_{s}}{R_{s h}}
$$

where, following the traditional theory, the photocurrent $I_{L}$ depends on the solar irradiance, the diode saturation currents $I_{01}$ and $I_{02}$ are affected by the cell temperature, $n_{1}=a_{1} N_{c s} k / q$ and $n_{2}=a_{2} N_{c s} k / q$ are the diode quality factors, $a_{1}$ and $a_{2}$ are the diode shape factors, $N_{c s}$ is the number of cells of the panel that are connected in series. The values of $R_{s}, R_{s h}, I_{01}$ and $I_{02}$ variously affect the $I-V$ characteristic of the PV panel [3]. Because the evaluation of the parameters contained in the two-diode equivalent circuit is a complex problem, the one-diode equivalent circuit, depicted in Figure 2, was also considered.

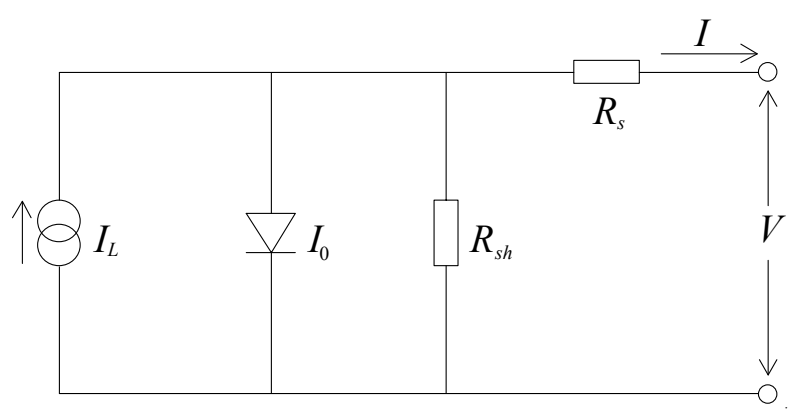

Figure 2. One-diode equivalent circuit for a PV panel.

Many authors have proposed analytical procedures for determining the model parameters on the basis of the performance data usually provided by manufacturers [4-48]. The identification of the parameters contained in the diode-based equivalent circuits has been also tackled exploring the possibility of using different procedures such as Lambert $W$-function, evolutionary algorithms, Padè approximants, genetic algorithms, cluster analysis, artificial neural networks, harmony search-based algorithms, small perturbations around the operating point and reduced forms [49-63]. Other authors have investigated some simplified versions of the one-diode equivalent circuit in order to obtain an adequate representation of the PV panel characteristics by means of a reduced number of model parameters. A large amount of simplified one-diode models, obtained by changing the used set of performance data, the adopted hypotheses and the analytical procedures for evaluating the model parameters, have been presented [64-72].

The selection of the model fit for purpose may be a difficult task that should carefully consider both the strong points and weaknesses of the examined method. Besides the achievable precision, each model has a different usability, as it needs specific performance data, which may be not available or difficult to extract from the available datasheets. The model also presents computation difficulties, which may require the use of mathematical tools ranging from simple algorithms to complex methods 
implemented in dedicated computational software. The usability is a qualitative parameter, whereas the accuracy achievable by a model requires a quantitative assessment. In order to select the simplified one-diode model which represents the best compromise between analytical complexity and expected accuracy, it is necessary to perform a complex synthesis of both qualitative and quantitative features. The criterion proposed in this paper, which is used to rate the performances of some of the most famous simplified one-diode models, can help researchers and designers, working in the area of photovoltaic systems, to select the model fit for purpose.

The paper is organised along the lines of a previous study regarding the one-diode models for PV modules [1]. The criterion adopts a three-level rating scale that considers the ease of finding the data used by the analytical procedure, the simplicity of the mathematical tools needed to perform calculations and the accuracy achieved in calculating the current and power. Section 2 presents the simplified one-diode model and the effects of the series resistance on the shape of the $I-V$ curves; Section 3 lists chronologically the most famous simplified one-diode equivalent circuits along with the used performance data, the required mathematical tools and the operative steps to obtain the model parameters. In Section 4, the accuracy of the tested simplified one-diode models is evaluated by calculating the $I-V$ characteristics of some PV modules and comparing them with the performance curves issued by manufacturers. A criterion for rating the usability and accuracy of the analysed one-diode models is presented in Section 5. The minute descriptions of the mathematical procedures used to get the explicit or implicit expressions necessary to calculate the model parameters are listed in the Appendix A; such a review also contains the sequence of operative steps to easily calculate the model parameters.

\section{The Simplified One-Diode Equivalent Circuit}

The one-diode model depicted in Figure 2 is described by the well-known equation:

$$
I=I_{L}-I_{0}\left(e^{\frac{V+I R_{s}}{n T}}-1\right)-\frac{V+I R_{S}}{R_{s h}}
$$

where diode quality factor $n=a N_{c s} k / q$ and $a$ is the diode shape factor. Despite its simplicity, the one-diode model adequately reproduces the $I-V$ characteristic at standard rating conditions (SRC)_irradiance $G_{r e f}=1000 \mathrm{~W} / \mathrm{m}^{2}$, cell temperature $T_{r e f}=25^{\circ} \mathrm{C}$ and average solar spectrum at AM 1.5-of most of the modern and efficient crystalline PV modules. Because of their small series resistance and great shunt resistance, crystalline PV modules show a good fill factor and, consequently, an $I-V$ characteristic with a very sharp bend. The model is based on parameters $I_{L}, I_{0}, n, R_{S}$ and $R_{s h}$ whose calculation generally requires the solution of an equation system containing five independent relations obtained from Equation (2) or from its derivative. The mathematical difficulties encountered in the simultaneous solution of the involved implicit transcendent equations have suggested solving the problem by introducing some simplifications in the one-diode equivalent model. The four-parameter model depicted in Figure 3, in which resistance $R_{s h}$ is set equal to infinity, has been often proposed.

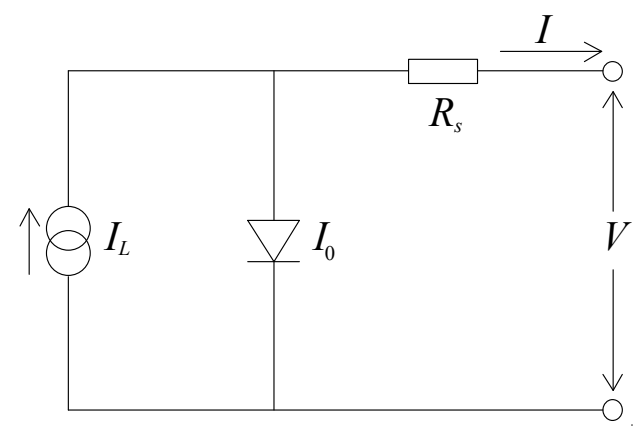

Figure 3. Four-parameter equivalent circuit for a PV panel. 
The four-parameter model is governed by the following equation:

$$
I=I_{L}-I_{0}\left(e^{\frac{V+I R_{S}}{n T}}-1\right)
$$

As shown in Figure 4, series resistance $R_{s}$ impacts the shape of the $I-V$ characteristic close and beyond the MPP, which is approximately set on the "knee" of the curve.

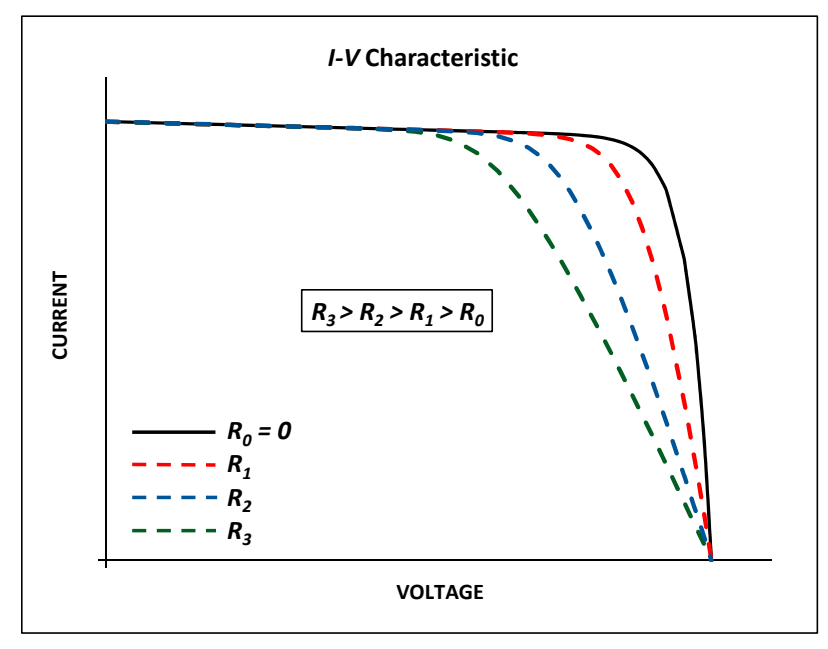

Figure 4. Effects of the series resistance on the $I-V$ characteristic.

At a constant value of the solar irradiance, if the series resistance is lowered, the internal dissipation of energy is reduced and the panel becomes more efficient; the MPP will slide towards right and the "knee" will be sharper because the value of the open circuit voltage is not affected by the series resistance. Conversely, smoother curves and greater values of $R_{s}$ characterize the PV cells that are made with more energy dissipative materials and/or present higher electrical connection resistances. The analytical procedures proposed to calculate the four-parameter model generally require the following input data, which are usually available in the manufacturer datasheets:

- $\quad$ open circuit voltage $V_{o c, r e f}$ and short circuit current $I_{s c, \text { ref }}$ at the SRC;

- $\quad$ voltage $V_{m p, r e f}$ and current $I_{m p, \text { ref }}$ at the MPP at the SRC;

- open circuit voltage temperature coefficient $\mu_{V, o c}$ and short circuit current temperature coefficient $\mu_{I, s c}$.

Sometimes, the number of series connected PV cells, or the derivative of the $I-V$ curve at the MPP are also required. Because of the presence of current $I$ in both terms of transcendent Equation (3), the solution of the four-equation system, which is necessary to calculate the model parameters, cannot be obtained by means of exact mathematical methods. To solve the problem, both approximate forms of the equations and numerical solving techniques have been used.

\section{Usability of the Simplified One-Diode Models}

Numerous procedures to calculate the parameters of the simplified one-diode model have been proposed. Some of these models were presented about 25 years ago. Nevertheless, they are still considered as effective and accurate as the most recent simplified one-diode models. Townsend [64] analysed several models of PV cells and panels and proposed a four-parameter model to be the most appropriate one for assessing the long-term performance of direct-coupled PV systems. In order to define the values of the model parameters, Townsend described three different procedures that in this paper are called Townsend n.1, Townsend n.2 and Townsend n.3, respectively. Other models were proposed by Duffie et al. [65], Xiao et al. [66], Ulapane et al. [67], Saloux et al. [68], 
Mahmoud et al. [69,70], Cristaldi et al. [71] and Averbukh et al. [72]. The model parameters are always evaluated by solving an equation system that represents the information related to the physical properties of the PV panels and/or geometrical conditions concerning the $I-V$ characteristics.

The usability of a procedure may be significantly lowered by the difficulties encountered in using it. For this reason to assess the usability rating it is necessary to explore the complete sequence of operative steps that permit to calculate the model parameters. Sometimes the solution of the equation system is obtained adopting some simplifying hypotheses and iterative procedures. Some models evaluate the parameters on the basis of a similar set of information, but do not adopt the same simplifying hypotheses and/or use different relations to describe the dependence on the cell temperature and/or the solar irradiance. A synthetic description of the used information, simplifying hypotheses and solving techniques is contained in the paper and the analytical procedures to calculate the model parameters are minutely described in the Appendix A. Because the simplifying hypotheses are quite realistic, the values of the model parameters obtained by the approximate procedure may result almost equal to the values calculated without recourse to mathematical simplifications. Such an occurrence has been observed for some of the analysed models and consequently produces very similar $I-V$ curves whose comparison may be considered trivial. Nevertheless, for the sake of completeness, the comparison of these models is also presented in this paper.

\subsection{Townsend n.1 Model}

The Townsend n.1 model [64] uses the following information:

(1) short circuit point $\left[I=I_{s c, r e f} ; V=0\right]$;

(2) open circuit point $\left[I=0 ; V=V_{o c, \text { ref }}\right]$;

(3) $\operatorname{MPP}\left[I=I_{m p, r e f} ; V=V_{m p, r e f}\right]$;

(4) derivative of power at the MPP $\left[\partial P / \partial V=0\right.$ at $\left.I=I_{m p, r e f} ; V=V_{m p, r e f}\right]$;

which are described by the four independent equations listed in the Appendix A. No simplifying hypothesis is assumed and the equation system is solved by means of the Newton-Raphson method.

\subsection{Townsend n.2 Model}

The Townsend n.2 model [64] is based on the same information of the Townsend n.1 model:

(1) short circuit point $\left[I=I_{s c, \text { ref }} ; V=0\right]$;

(2) open circuit point $\left[I=0 ; V=V_{o c, \text { ref }}\right]$;

(3) MPP $\left[I=I_{m p, r e f} ; V=V_{m p, r e f}\right]$;

(4) derivative of power at the MPP $\left[\partial P / \partial V=0\right.$ at $\left.I=I_{m p, r e f} ; V=V_{m p, r e f}\right]$.

The following hypotheses, which are usually verified for a PV module, are assumed:

$$
e^{\frac{I_{\text {sc, ref }} R_{s}}{n T_{\text {ref }}}} \approx 1 \quad e^{\frac{V_{o c, r e f}}{n T_{r e f}}}>>1 \quad e^{\frac{V_{m p, r e f}}{n T_{r e f}}}>>1
$$

and the model parameters can be calculated using the explicit equations described in the Appendix A.

\subsection{Townsend n.3 Model}

For the Townsend n.3 model [64] the following information is used:

(1) short circuit point $\left[I=I_{s c, r e f} ; V=0\right]$;

(2) open circuit point $\left[I=0 ; V=V_{o c, \text { ref }}\right]$;

(3) MPP $\left[I=I_{m p, r e f} ; V=V_{m p, r e f}\right]$;

(4) derivative of voltage at the open circuit point $\left[\partial V_{o c} / \partial T=\mu_{V, o c}\right.$ at $\left.G=1000 \mathrm{~W} / \mathrm{m}^{2}\right]$. 
The same hypotheses of Equation (4) are assumed. Due to the presence of implicit forms, the equation system is solved with the iterative procedure described in the Appendix A.

\subsection{Duffie and Beckman Model}

The Duffie and Beckman model [65] is based on the same information used by the Townsend n.3 model:

(1) short circuit point $\left[I=I_{s c, r e f} ; V=0\right]$;

(2) open circuit point $\left[I=0 ; V=V_{o c, \text { ref }}\right]$;

(3) $\operatorname{MPP}\left[I=I_{m p, r e f} ; V=V_{m p, r e f}\right]$;

(4) derivative of voltage at the open circuit point $\left[\partial V_{o c} / \partial T=\mu_{V, o c}\right.$ at $\left.G=1000 \mathrm{~W} / \mathrm{m}^{2}\right]$.

Due to the adoption of the hypotheses described in Equation (4), the model does not require any iterative procedure and parameters $I_{L, \text { ref }}, I_{0, \text { ref }}, R_{S}$ and $n$ can be calculated with the explicit equations listed in the Appendix A.

\subsection{Xiao, Dunford and Capel Model}

Xiao et al. [66] presented a four-parameter model whose parameters are calculated on the basis of the following information:

(1) short circuit point $\left[I=I_{s c, r e f} ; V=0\right]$;

(2) open circuit point $\left[I=0 ; V=V_{o c, r e f}\right]$;

(3) $\mathrm{MPP}\left[I=I_{m p, r e f} ; V=V_{m p, r e f}\right]$;

(4) derivative of power at the MPP $\left[\partial P / \partial V=0\right.$ at $\left.I=I_{m p, r e f} ; V=V_{m p, r e f}\right]$.

Assuming the following hypothesis:

$$
e^{\frac{I_{s c, r e f} R_{s}}{n T_{r e f}}} \approx 1
$$

parameters $I_{L, r e f}, I_{0, r e f}, n$ and $R_{S}$ can be calculated with the iterative procedure described in the Appendix A.

3.6. Ulapane, Dhanapala, Wickramasinghe, Abeyratne, Rathnayake and Binduhewa Model

The model proposed by Ulapane et al. [67] uses the same information and hypothesis adopted by Xiao et al.

(1) short circuit point $\left[I=I_{s c, \text { ref }} ; V=0\right]$;

(2) open circuit point $\left[I=0 ; V=V_{o c, \text { ref }}\right]$;

(3) $\mathrm{MPP}\left[I=I_{m p, r e f} ; V=V_{m p, r e f}\right]$;

(4) derivative of power at the MPP $\left[\partial P / \partial V=0\right.$ at $\left.I=I_{m p, r e f} ; V=V_{m p, r e f}\right]$.

The model parameters are calculated with the iterative procedure described in the Appendix A. A different approach is used to describe the physical behaviour of the PV panel for conditions far from the SRC.

\subsection{Saloux, Teyssedou and Sorin Model}

A three-parameter model, in which resistance $R_{s}$ is set equal to zero, was proposed by Saloux at al. [68]. The model uses the following simplified analytical equation:

$$
I=I_{L}-I_{0}\left(e^{\frac{V}{n T}}-1\right)
$$


The model parameters are calculated imposing that the following points belong to the $I-V$ curve:

(1) short circuit point $\left[I=I_{s c, r e f} ; V=0\right]$;

(2) open circuit point $\left[I=0 ; V=V_{o c, \text { ref }}\right]$;

(3) $\operatorname{MPP}\left[I=I_{m p, r e f} ; V=V_{m p, r e f}\right]$.

Assuming the following hypotheses:

$$
e^{\frac{V_{\text {oc, ref }}}{n T_{\text {ref }}}}>>1 \quad e^{\frac{V_{m p, r e f}}{n T_{\text {ref }}}}>>1
$$

the parameters of the model can be easily calculated with the explicit equations listed in the Appendix A.

\subsection{Mahmoud, Xiao and Zeineldin n.1 Model}

Mahmoud et al. [69] presented a three-parameter model based on Equation (6) whose parameters were calculated using the same information adopted by Saloux et al.

(1) short circuit point $\left[I=I_{s c, r e f} ; V=0\right]$;

(2) open circuit point $\left[I=0 ; V=V_{o c, r e f}\right]$;

(3) $\mathrm{MPP}\left[I=I_{m p, r e f} ; V=V_{m p, r e f}\right]$.

Numerical methods are used to solve the equations listed in the Appendix A. A different approach is adopted to describe the physical behaviour of the PV panel for conditions far from the SRC.

\subsection{Cristaldi, Faifer, Rossi and Toscani Model}

Cristaldi et al. [71] proposed a four-parameter model based on the following information:

(1) short circuit point $\left[I=I_{s c, r e f} ; V=0\right]$;

(2) open circuit point $\left[I=0 ; V=V_{o c, \text { ref }}\right]$;

(3) $\operatorname{MPP}\left[I=I_{m p, r e f} ; V=V_{m p}\right.$,ref $]$;

(4) derivative of power at the MPP $\left[\partial P / \partial I=0\right.$ at $\left.I=I_{m p, r e f} ; V=V_{m p, r e f}\right]$.

The following hypotheses are adopted:

$$
e^{\frac{I_{s c, \text { ref }} R_{S}}{n T_{\text {ref }}}} \approx 1 \quad e^{\frac{V_{o c, \text { ref }}}{n T_{\text {ref }}}}>>1 \quad e^{-\frac{V_{o c, r e f}}{n T_{r e f}}} \approx 0
$$

and the model parameters are calculated by means of the analytical procedure based on the explicit equations listed in the Appendix A.

\subsection{Averbukh, Lineykin and Kuperman Model}

The model proposed by Averbukh et al. [72] uses on the same information used by Cristaldi et al.

(1) short circuit point $\left[I=I_{s c, \text { ref }} ; V=0\right]$;

(2) open circuit point $\left[I=0 ; V=V_{o c, \text { ref }}\right]$;

(3) $\mathrm{MPP}\left[I=I_{m p, r e f} ; V=V_{m p, r e f}\right]$;

(4) derivative of power at the MPP $\left[\partial P / \partial I=0\right.$ at $I=I_{m p, r e f} ; V=V_{m p}$,ref $]$.

Instead of using Equation (3), the following equivalent expression is adopted:

$$
V=n T \ln \left(\frac{I_{L}-I}{I_{0}}+1\right)-I R_{S}
$$


The equations listed in the Appendix A, which describe the short circuit, open circuit, maximum power points and the derivative of power at the MPP, are normalized using six per-unit dimensionless parameters and solved by means of a modern dedicate software.

\subsection{Mahmoud, Xiao and Zeineldin n.2 Model}

Mahmoud et al. [70] presented a procedure to automatically transform the five-parameter model into a four-parameter model, in which only the series resistance, or only the shunt resistance, is present. The equivalent circuit representation depends on the physical properties of the simulated PV panel. The model is based on the same information used by Cristaldi et al. and Averbukh et al.

(1) short circuit point $\left[I=I_{s c, r e f} ; V=0\right]$;

(2) open circuit point $\left[I=0 ; V=V_{o c, \text { ref }}\right]$;

(3) $\mathrm{MPP}\left[I=I_{m p, r e f} ; V=V_{m p, r e f}\right]$;

(4) derivative of power at the MPP $\left[\partial P / \partial I=0\right.$ at $\left.I=I_{m p, r e f} ; V=V_{m p, r e f}\right]$;

and assumes the following hypotheses:

$$
e^{\frac{I_{s c \text { ref }} R_{s}}{n T_{\text {ref }}}} \approx 1 \quad \frac{I_{s c, \text { ref }} R_{s}}{R_{s h}} \approx 0 \quad R_{s}\left(\frac{I_{0}}{n T_{\text {ref }}} e^{\frac{V_{m p, r e f}+I_{m p}, \text { ref }}{n T_{\text {ref }}}}+\frac{1}{R_{s h}}\right)<<1
$$

In order to state the equivalent circuit representation and calculate the model parameters, the procedure described in the Appendix A is adopted.

\subsection{Summary of the Information Used by the Models}

In order to better appreciate the analogies and differences between the various models, the used information, hypotheses and solving tools are summarised in Table 1.

Table 1. Summary of the information and solving techniques used by the simplified one-diode models.

\begin{tabular}{|c|c|c|c|c|c|c|c|}
\hline \multirow[b]{2}{*}{ MODEL } & \multicolumn{5}{|c|}{ Information Used for Calculation } & \multicolumn{2}{|c|}{ Solving Techniques } \\
\hline & SCP & OCP & MPP & DMPP & DOCV & $\begin{array}{l}\text { Simplifying } \\
\text { Hypotheses }\end{array}$ & $\begin{array}{c}\text { Mathematical } \\
\text { Tools }\end{array}$ \\
\hline Townsend n.1 & $X$ & $X$ & $X$ & $X$ & & & NRM \\
\hline Townsend n.2 & $X$ & $X$ & $X$ & $X$ & & $X$ & SC \\
\hline Townsend n.3 & $X$ & $X$ & $X$ & & $X$ & & IP \\
\hline Duffie \& Beckman & $X$ & $X$ & $X$ & & $X$ & $X$ & SC \\
\hline Xiao et al. & $X$ & $X$ & $X$ & $X$ & & $X$ & IP \\
\hline Ulapane et al. & $X$ & $X$ & $X$ & $X$ & & $X$ & IP \\
\hline Saloux et al. & $X$ & $X$ & $X$ & & & $X$ & SC \\
\hline Mahmoud et al. n.1 & $X$ & $X$ & $X$ & & & & NS \\
\hline Cristaldi et al. & $X$ & $X$ & $X$ & $X$ & & $X$ & SC \\
\hline Averbukh et al. & $X$ & $X$ & $X$ & $X$ & & & NS \\
\hline Mahmoud et al. n.2 & $X$ & $X$ & $x$ & $X$ & & $X$ & SC \\
\hline
\end{tabular}

It can be observed that the same information is often shared among different models. For this reason one may suppose that these models should be quite similar and yield the same results. Actually, because different simplifying hypotheses, solving techniques and relations to evaluate the PV panel performance curves at conditions different from SRC are adopted, each model has a particular capability to reproduce the $I-V$ characteristics by means of mathematical approaches, which can be very simple or require the implementation of iterative routines and the use of specific mathematical methods and computer software. 


\section{Accuracy of the Simplified One-Diode Models}

With the aim of verifying the accuracy of the analysed procedures, a comparison between the simplified one-diode models was made using the $I-V$ characteristics extracted from the manufacturer datasheets. For the sake of brevity only two PV modules, based on different technologies, were considered. Obviously, even using a greater number of PV modules, the comparison would never be exhaustive because the results are strongly affected by the particular shape of the considered $I-V$ characteristics. Moreover, the purpose of this paper is not ranking the best or the worst among the analysed models, but only defining the range of predictable precision in order to calibrate the criterion. The performance data of the simulated PV modules are listed in Table 2.

Table 2. Performance data of the simulated PV panels.

\begin{tabular}{ccccccccc}
\hline Panel & Type & $N_{c s}$ & $V_{o c, \text { ref }}(\mathrm{V})$ & $I_{s c, \text { ref }}(\mathrm{A})$ & $V_{m p, \text { ref }}(\mathrm{V})$ & $\boldsymbol{I}_{\boldsymbol{m}, \text { ref }}(\mathrm{A})$ & $\mu_{V, o c}\left(\mathrm{~V} /{ }^{\circ} \mathrm{C}\right)$ & $\mu_{I, s c}\left(\mathrm{~A} /{ }^{\circ} \mathrm{C}\right)$ \\
\hline $\begin{array}{c}\text { Kyocera } \\
\text { KD245GH-4FB2 }\end{array}$ & Poly & 60 & 36.90 & 8.91 & 29.80 & 8.23 & $-1.33 \times 10^{-1}$ & $5.35 \times 10^{-3}$ \\
\hline $\begin{array}{c}\text { Sanyo } \\
\text { HIT-240 HDE4 }\end{array}$ & HIT & 60 & 43.60 & 7.37 & 35.50 & 6.77 & $-1.09 \times 10^{-1}$ & $2.21 \times 10^{-3}$ \\
\hline
\end{tabular}

Considering both the constant solar irradiance and the constant cell temperature curves, numerous points were extracted from the $I-V$ characteristics issued by the manufacturers in order to get a reliable comparison between the calculated and the measured data. Tables 3 and 4 list the values of the parameters evaluated with the analysed models.

Table 3. Model parameters of the Kyocera KD245GH-4FB2 at the SRC.

\begin{tabular}{ccccc}
\hline Model & $\boldsymbol{I}_{\boldsymbol{L}, \boldsymbol{r e f}}(\mathbf{A})$ & $\boldsymbol{I}_{\mathbf{0 , r e f}}(\mathbf{A})$ & $\boldsymbol{n} \mathbf{( V / K )}$ & $\boldsymbol{R}_{\boldsymbol{S}}(\boldsymbol{\Omega})$ \\
\hline Townsend n.1 & 8.9100 & $3.7695 \times 10^{-6}$ & $8.4332 \times 10^{-3}$ & 0.0767 \\
Townsend n.2 & 8.9100 & $8.7846 \times 10^{-9}$ & $5.9681 \times 10^{-3}$ & 0.3064 \\
Townsend n.3 & 8.9100 & $7.6306 \times 10^{-5}$ & $1.0607 \times 10^{-2}$ & -0.1260 \\
Duffie et al. & 8.9100 & $7.6309 \times 10^{-5}$ & $1.0607 \times 10^{-2}$ & -0.1260 \\
Xiao et al. & 8.9100 & $1.6678 \times 10^{-6}$ & $7.9893 \times 10^{-3}$ & 0.1180 \\
Ulapane et al. & 8.9100 & $1.6670 \times 10^{-6}$ & $7.9890 \times 10^{-3}$ & 0.1181 \\
Saloux et al. & 8.9100 & $1.3890 \times 10^{-5}$ & $9.2557 \times 10^{-3}$ & - \\
Mahmoud et al. n.1 & 8.9100 & $1.3892 \times 10^{-5}$ & $9.2558 \times 10^{-3}$ & - \\
Cristaldi et al. & 8.9100 & $1.6670 \times 10^{-6}$ & $7.9890 \times 10^{-3}$ & 0.1181 \\
Averbukh et al. & 8.9100 & $1.6674 \times 10^{-6}$ & $7.9891 \times 10^{-3}$ & 0.1181 \\
Mahmoud et al. n.2 & 8.9100 & $2.7625 \times 10^{-6}$ & $8.2583 \times 10^{-3}$ & 0.0930 \\
\hline
\end{tabular}

Table 4. Model parameters of the Sanyo HIT-240 HDE4 at the SRC.

\begin{tabular}{ccccc}
\hline Model & $\boldsymbol{I}_{\boldsymbol{L}, \boldsymbol{r e f}} \mathbf{( A )}$ & $\boldsymbol{I}_{\mathbf{0}, \boldsymbol{r e f}} \mathbf{( A )}$ & $\boldsymbol{n} \mathbf{( V / K})$ & $\boldsymbol{R}_{\boldsymbol{s}}(\boldsymbol{\Omega})$ \\
\hline Townsend n.1 & 7.3700 & $7.5495 \times 10^{-6}$ & $1.0603 \times 10^{-2}$ & 0.0252 \\
Townsend n.2 & 7.3700 & $4.1652 \times 10^{-8}$ & $7.7001 \times 10^{-3}$ & 0.3459 \\
Townsend n.3 & 7.3700 & $3.9917 \times 10^{-6}$ & $1.0135 \times 10^{-2}$ & 0.0769 \\
Duffie et al. & 7.3700 & $3.9919 \times 10^{-6}$ & $1.0135 \times 10^{-2}$ & 0.0769 \\
Xiao et al. & 7.3700 & $6.3630 \times 10^{-6}$ & $1.0473 \times 10^{-2}$ & 0.0395 \\
Ulapane et al. & 7.3700 & $6.3587 \times 10^{-6}$ & $1.0473 \times 10^{-2}$ & 0.0396 \\
Saloux et al. & 7.3700 & $1.0092 \times 10^{-5}$ & $1.0831 \times 10^{-2}$ & - \\
Mahmoud et al. n.1 & 7.3700 & $1.0093 \times 10^{-5}$ & $1.0831 \times 10^{-2}$ & - \\
Cristaldi et al. & 7.3700 & $6.3576 \times 10^{-6}$ & $1.0473 \times 10^{-2}$ & 0.0396 \\
Averbukh et al. & 7.3700 & $6.3588 \times 10^{-6}$ & $1.0473 \times 10^{-2}$ & 0.0396 \\
Mahmoud et al. n.2 & 7.3700 & $7.0646 \times 10^{-6}$ & $1.0553 \times 10^{-2}$ & 0.0308 \\
\hline
\end{tabular}


For the analysed PV modules, the procedure proposed by the Mahmoud et al. n.2 model always generated an equivalent circuit representation in which only the series resistance is present. The values of Tables 3 and 4 were used to calculate the $I-V$ characteristics of the selected PV panels. The Townsend n.3 model was not considered because it perfectly corresponds to the Duffie et al. model. The Cristaldi et al. model was not taken into account because the $I-V$ curves calculated with the model perfectly overlap the characteristics obtained from the Ulapane et al. model for all values of solar irradiance and cell temperature. Actually, the results are numerically indistinguishable because the only difference, which should make the Cristaldi et al. model a bit more imprecise, is due to the last two hypotheses described in Equation (8), which are thoroughly confirmed by real PV modules. In Figures 5-10 the $I-V$ curves, evaluated at $T=25^{\circ} \mathrm{C}$, are compared with the characteristics issued by manufacturers.

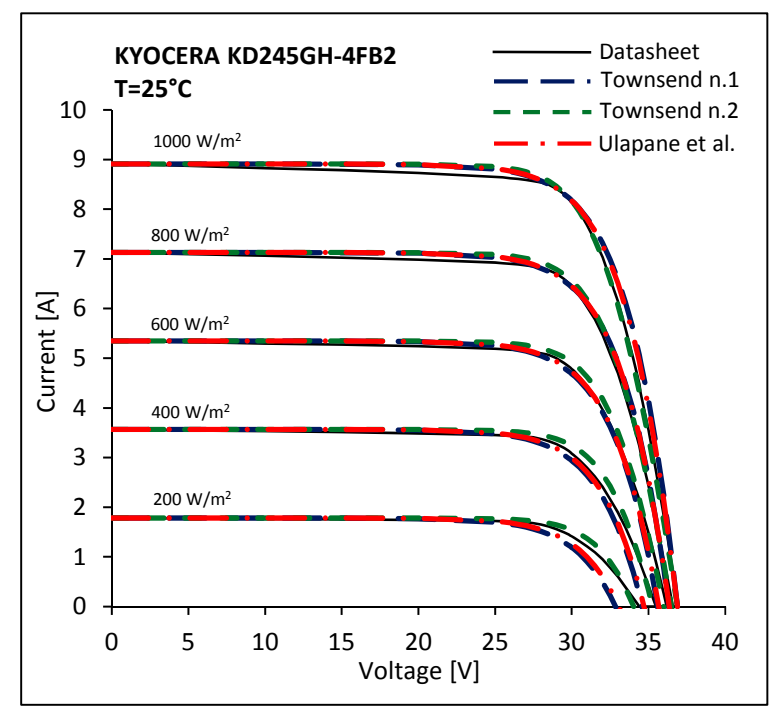

Figure 5. Comparison between the issued $I-V$ characteristics of the Kyocera KD245GH-4FB2 at $T=25^{\circ} \mathrm{C}$ and the characteristics calculated by means of the Townsend n.1, the Townsend n.2 and the Ulapane et al. models.

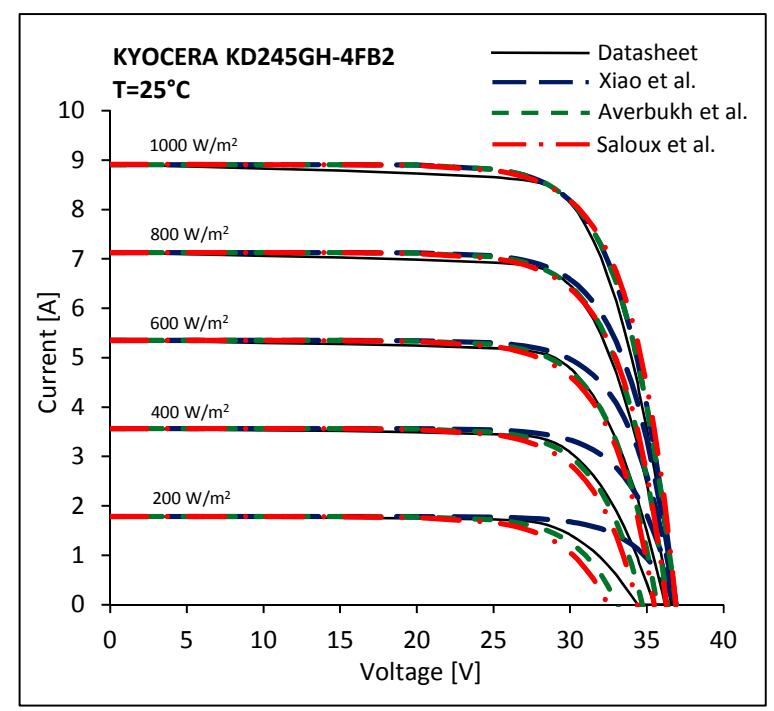

Figure 6. Comparison between the issued $I-V$ characteristics of the Kyocera KD245GH-4FB2 at $T=25^{\circ} \mathrm{C}$ and the characteristics calculated by means of the Xiao et al. the Averbukh et al. and the Saloux et al. models. 


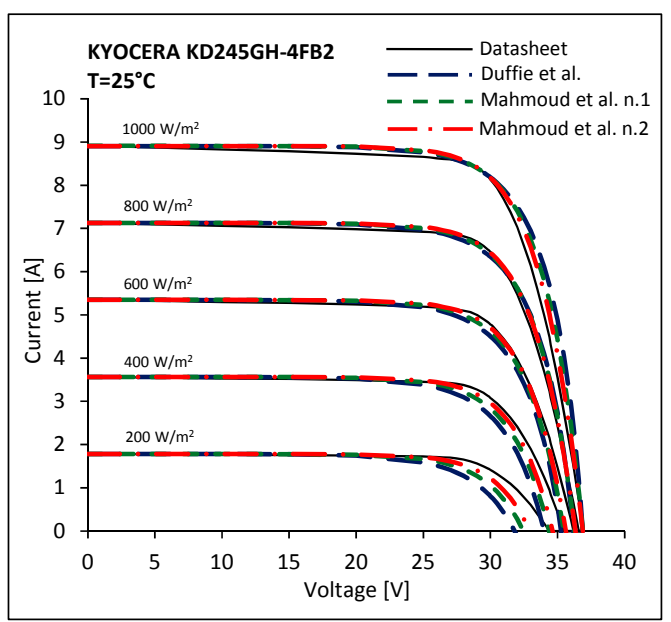

Figure 7. Comparison between the issued $I-V$ characteristics of the Kyocera KD245GH-4FB2 at $T=25^{\circ} \mathrm{C}$ and the characteristics calculated by means of the Duffie et al. and the Mahmoud et al. models.

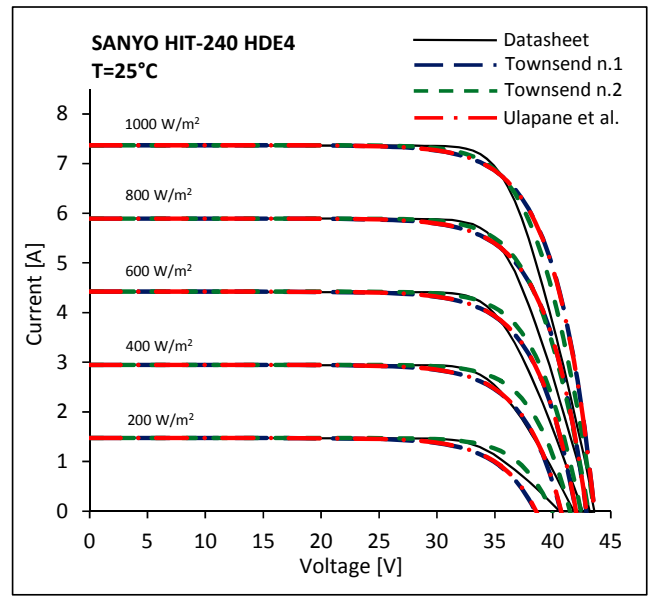

Figure 8. Comparison between the issued $I-V$ characteristics of the Sanyo HIT-240 HDE4 at $T=25{ }^{\circ} \mathrm{C}$ and the characteristics calculated by means of the Townsend $n .1$, the Townsend $n .2$ and the Ulapane et al. models.

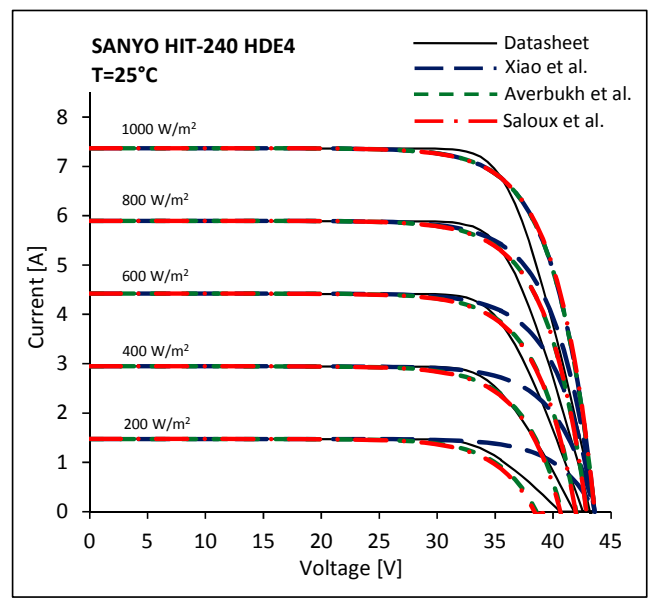

Figure 9. Comparison between the issued $I-V$ characteristics of the Sanyo HIT-240 HDE4 at $T=25^{\circ} \mathrm{C}$ and the characteristics calculated by means of the Xiao et al., the Averbukh et al. and the Saloux et al. models. 


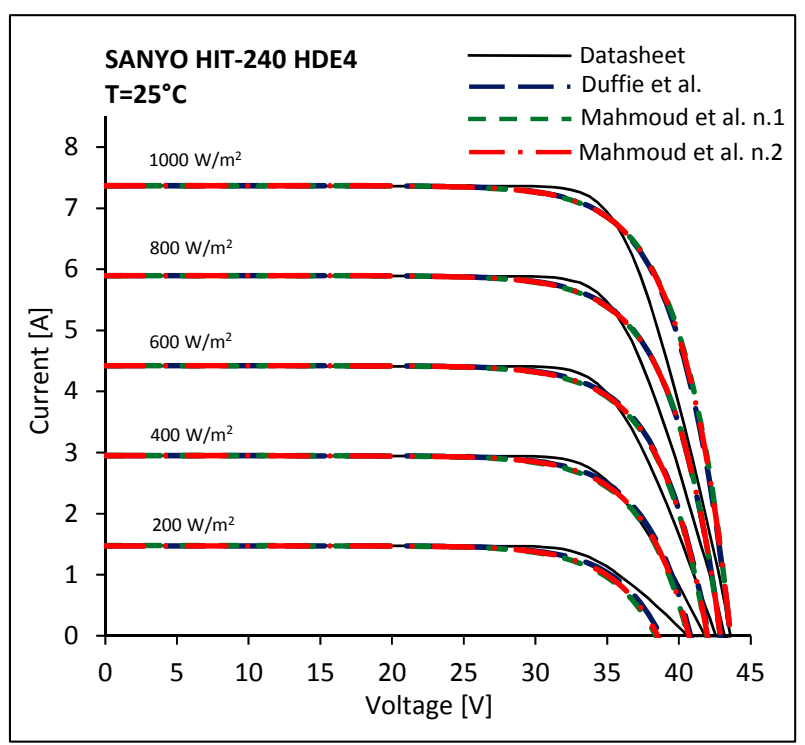

Figure 10. Comparison between the issued $I-V$ characteristics of the Sanyo HIT-240 HDE 4 at $T=25^{\circ} \mathrm{C}$ and the characteristics calculated by means of the Duffie et al. and the Mahmoud et al. models.

Because the Xiao et al. the Ulapane et al. and the Averbukh et al. models are based on the same information, it is not surprising that the $I-V$ curves at the SRC result quite similar. An analogous observation is valid for the Saloux et al. and the Mahmoud et al. n.1 models. Conversely, significant differences are expected for values of solar irradiance and cell temperature different from the SRC. Figures 11-16 depict the $I-V$ curves evaluated at $G=1000 \mathrm{~W} / \mathrm{m}^{2}$ and the characteristics issued by manufacturers.

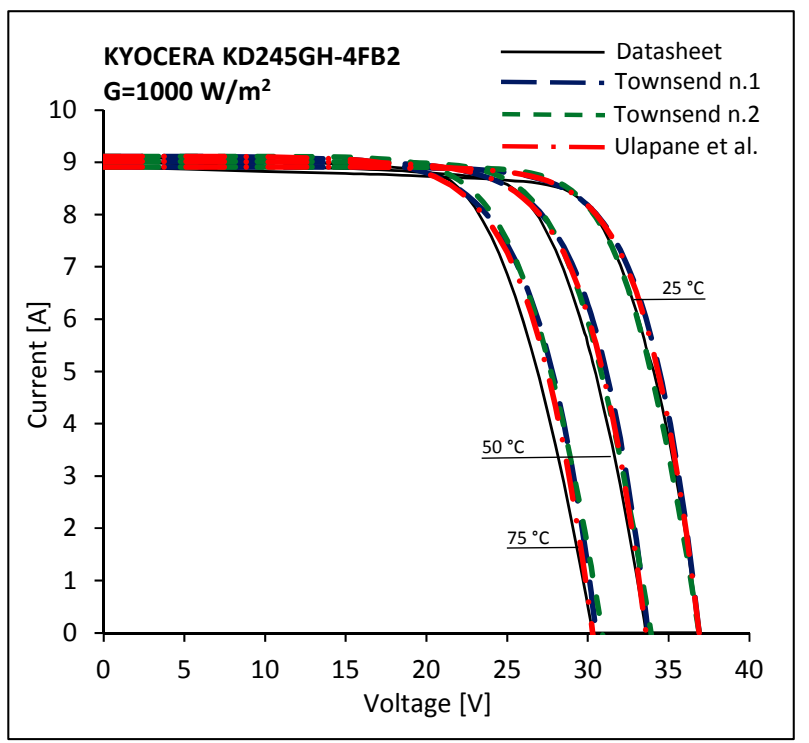

Figure 11. Comparison between the issued $I-V$ characteristics of the Kyocera KD245GH-4FB2 at $G=1000 \mathrm{~W} / \mathrm{m}^{2}$ and the characteristics calculated by means of the Townsend $\mathrm{n} .1$, the Townsend $\mathrm{n} .2$ and the Ulapane et al. models. 


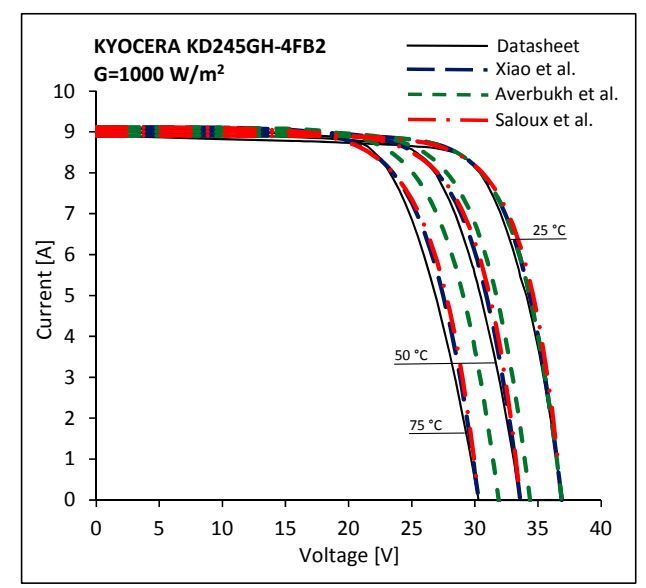

Figure 12. Comparison between the issued $I-V$ characteristics of the Kyocera KD245GH-4FB2 at $G=1000 \mathrm{~W} / \mathrm{m}^{2}$ and the characteristics calculated by means of the Xiao et al. the Averbukh et al. and the Saloux et al. models.

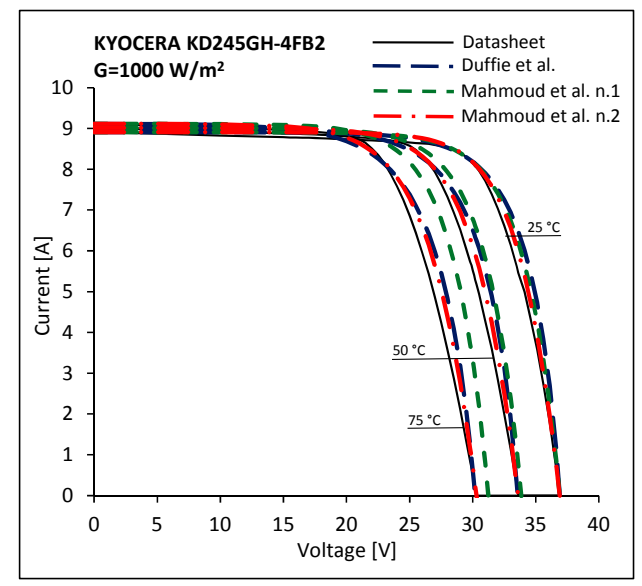

Figure 13. Comparison between the issued $I-V$ characteristics of the Kyocera KD245GH-4FB2 at $G=1000 \mathrm{~W} / \mathrm{m}^{2}$ and the characteristics calculated by means of the Duffie et al. and the Mahmoud et al. models.

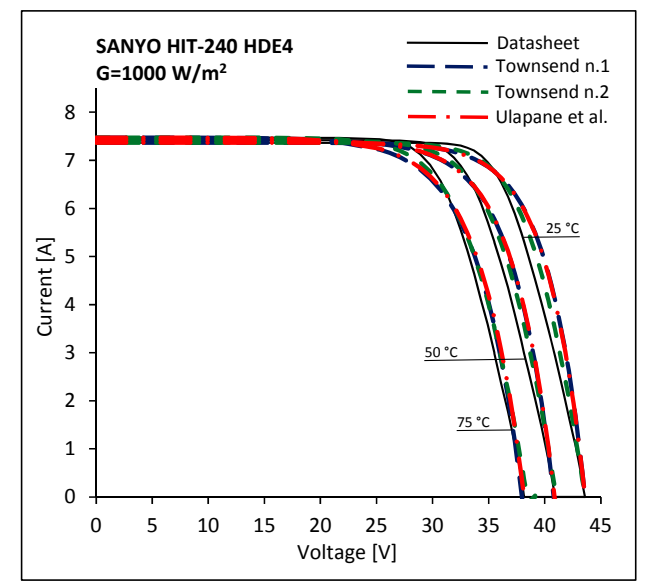

Figure 14. Comparison between the issued $I-V$ characteristics of the Sanyo HIT-240 HDE4 at $G=1000 \mathrm{~W} / \mathrm{m}^{2}$ and the characteristics calculated by means of the Townsend $\mathrm{n} .1$, the Townsend n.2 and the Ulapane et al. models. 


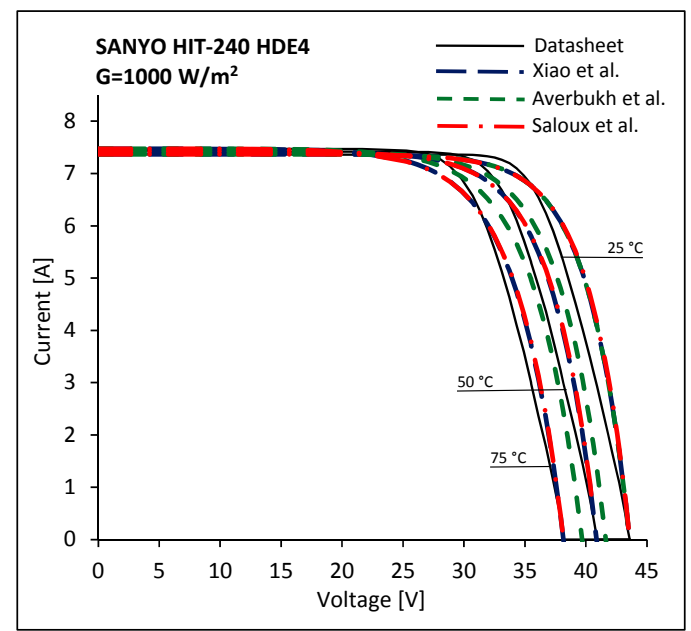

Figure 15. Comparison between the issued $I-V$ characteristics of the Sanyo HIT-240 HDE4 at $\mathrm{G}=1000 \mathrm{~W} / \mathrm{m}^{2}$ and the characteristics calculated by means of the Xiao et al. the Averbukh et al. and the Saloux et al. models.

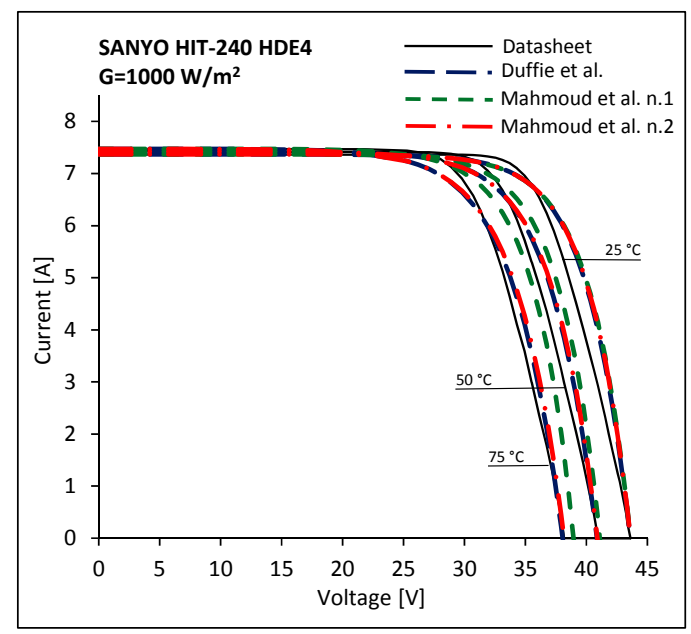

Figure 16. Comparison between the issued $I-V$ characteristics of the Sanyo HIT-240 HDE4 at $G=1000 \mathrm{~W} / \mathrm{m}^{2}$ and the characteristics calculated by means of the Duffie et al. and the Mahmoud et al. models.

Observing Figures 5-16 it can be generally deduced that all models result less accurate for voltage values greater than the MPP voltage. Moreover, it can be also noted that the simplified one-diode models are more precise if they are used to evaluate the $I-V$ characteristics of the Kyocera PV panel. This occurrence may be due to the different shape of the $I-V$ curves used to compare the analysed models. Actually, the $I-V$ characteristics of the Sanyo module generally show sharper "knees" close to the MPP, probably due to the used heterojunction with intrinsic thin layer (HIT) technology. Moreover, it can be observed that models that use similar values of the parameters listed in Tables 2 and 3 yield different $I-V$ curves for values of the solar irradiance and the cell temperature far from the SRC; this condition is obviously due to the different approaches adopted to describe the effects of the solar irradiance and the cell temperature. In this respect, the models of Xiao et al. Mahmoud et al. n.1 and of Averbukh et al. seem to be less accurate. In order to quantify the accuracy of the analysed models, the mean absolute difference (MAD) for current and power was calculated using the following expressions:

$$
\operatorname{MAD}(I)=\frac{1}{N} \sum_{j=1}^{N}\left|I_{c a l c, j}-I_{i s s, j}\right|
$$




$$
\operatorname{MAD}(P)=\frac{1}{N} \sum_{j=1}^{N}\left|V_{i s s, j} I_{\text {calc }, j}-V_{i s s, j} I_{i s s, j}\right|
$$

in which $V_{i s s, j}$ and $I_{i s s, j}$ are the voltage and current of the $j$-th point extracted from the $I-V$ characteristics issued by manufacturers, $I_{\text {calc }, j}$ is the value of the current calculated in correspondence of $V_{i s s, j}$ and $N$ is the number of extracted points. Moreover, in order to assess the range of dispersion of the results, also the maximum difference (MD) for current and power was evaluated using the following relations:

$$
\begin{gathered}
\operatorname{MD}(I)=\operatorname{MAX}\left[I_{\text {calc }, j}-I_{i s s, j}\right] \\
\operatorname{MD}(P)=\operatorname{MAX}\left[V_{i s s, j} I_{\text {calc }, j}-V_{i s s, j} I_{i s s, j}\right]
\end{gathered}
$$

In Tables 5 and 6 , the percentage ratios of $\operatorname{MAD}(I)$ to the current at the issued MPP, and of $\operatorname{MAD}(P)$

\begin{tabular}{|c|c|c|c|c|c|c|c|c|c|}
\hline \multirow{3}{*}{ PV Panel } & \multirow{2}{*}{$\begin{array}{l}I-V \text { Characteristic } \\
\text { Irradiance }\left(\mathrm{W} / \mathrm{m}^{2}\right)\end{array}$} & \multicolumn{8}{|c|}{$\operatorname{MAD}(I) / I_{m p, r e f}(\%)$} \\
\hline & & 200 & 400 & 600 & 800 & 1000 & 1000 & 1000 & Average \\
\hline & Temperature $\left({ }^{\circ} \mathrm{C}\right)$ & 25 & 25 & 25 & 25 & 25 & 50 & 75 & Value \\
\hline \multirow{9}{*}{$\begin{array}{c}\text { Kyocera } \\
\text { KD245GH-4FB2 }\end{array}$} & Townsend n.1 model & 2.05 & 2.10 & 1.41 & 1.25 & 2.43 & 3.88 & 4.76 & 2.56 \\
\hline & Townsend n. 2 model & 0.97 & 1.48 & 1.40 & 1.28 & 1.09 & 3.20 & 6.28 & 2.24 \\
\hline & Duffie et al. model & 4.56 & 4.48 & 2.96 & 1.74 & 4.54 & 4.63 & 4.11 & 3.86 \\
\hline & Xiao et al. model & $\overline{4.26}$ & $\underline{5.25}$ & $\underline{4.73}$ & $\underline{3.94}$ & $\overline{2.02}$ & 2.69 & 2.71 & 3.66 \\
\hline & Ulapane et al. model & 1.66 & $\overline{1.51}$ & $\overline{1.06}$ & $\overline{1.14}$ & 2.02 & 2.69 & 2.71 & 1.83 \\
\hline & Saloux et al. model & 2.95 & 2.66 & 1.82 & 1.47 & 3.22 & 3.74 & 3.77 & 2.81 \\
\hline & Mahmoud et al. n.1 model & 2.95 & 2.66 & 1.82 & 1.47 & 3.22 & 6.63 & 14.39 & $\underline{4.74}$ \\
\hline & Averbukh et al. model & 1.66 & 1.51 & 1.06 & 1.14 & 2.02 & $\underline{7.48}$ & $\underline{15.03}$ & $\overline{4.27}$ \\
\hline & Mahmoud et al. n.2 model & 1.82 & 1.86 & 1.26 & 1.20 & 2.27 & $\overline{2.89}$ & $\overline{2.89}$ & 2.03 \\
\hline \multirow{9}{*}{$\begin{array}{l}\text { Sanyo HIT-240 } \\
\text { HDE4 }\end{array}$} & Townsend n.1 model & 1.60 & 1.18 & 1.99 & 3.21 & 5.21 & 4.31 & 3.47 & 3.00 \\
\hline & Townsend n.2 model & 0.92 & 1.96 & 2.81 & 2.69 & 2.63 & 2.92 & 3.18 & 2.44 \\
\hline & Duffie et al. model & 1.30 & 1.05 & 2.02 & 3.09 & 4.79 & 4.08 & 3.35 & 2.81 \\
\hline & Xiao et al. model & $\underline{4.19}$ & $\underline{5.97}$ & $\underline{6.69}$ & $\underline{6.04}$ & 5.10 & 4.53 & 3.90 & $\underline{5.20}$ \\
\hline & Ulapane et al. model & $\overline{1.64}$ & $\overline{1.14}$ & $\overline{1.99}$ & $\overline{3.18}$ & 5.10 & 4.53 & 3.90 & 3.07 \\
\hline & Saloux et al. model & 1.80 & 1.29 & 1.98 & 3.26 & $\underline{5.42}$ & 4.83 & 4.19 & 3.25 \\
\hline & Mahmoud et al. n.1 model & 1.80 & 1.29 & 1.98 & 3.26 & $\underline{5.42}$ & 6.85 & 11.40 & 4.57 \\
\hline & Averbukh et al. model & 1.64 & 1.14 & 1.99 & 3.18 & $\overline{5.10}$ & $\underline{8.55}$ & $\underline{13.13}$ & 4.96 \\
\hline & Mahmoud et al. n.2 model & 1.73 & 1.17 & 1.99 & 3.19 & 5.17 & 4.59 & 3.96 & 3.11 \\
\hline
\end{tabular}
to the rated maximum power, are listed.

Table 5. Percentage ratio of $\operatorname{MAD}(I)$ to the rated current at the MPP.

\begin{tabular}{|c|c|c|c|c|c|c|c|c|c|}
\hline \multirow{3}{*}{ PV Panel } & \multirow{2}{*}{$\begin{array}{l}I-V \text { Characteristic } \\
\text { Irradiance }\left(\mathrm{W} / \mathrm{m}^{2}\right)\end{array}$} & \multicolumn{8}{|c|}{$\operatorname{MAD}(P) / V_{m p, r e f} I_{m p, r e f}(\%)$} \\
\hline & & 200 & 400 & 600 & 800 & 1000 & 1000 & 1000 & Average \\
\hline & Temperature $\left({ }^{\circ} \mathrm{C}\right)$ & 25 & 25 & 25 & 25 & 25 & 50 & 75 & Value \\
\hline \multirow{9}{*}{$\begin{array}{c}\text { Kyocera } \\
\text { KD245GH-4FB2 }\end{array}$} & Townsend n.1 model & 2.07 & 2.23 & 1.49 & 1.29 & 2.61 & 3.74 & 4.36 & 2.54 \\
\hline & Townsend n.2 model & 0.97 & 1.48 & 1.37 & 1.22 & 1.05 & 2.97 & 5.71 & 2.11 \\
\hline & Duffie et al. model & 4.49 & 4.63 & 3.12 & 1.84 & $\underline{5.10}$ & 4.55 & 3.66 & 3.91 \\
\hline & Xiao et al. model & $\underline{4.71}$ & $\underline{5.85}$ & $\underline{5.26}$ & $\underline{4.35}$ & $\overline{2.13}$ & 2.49 & 2.37 & 3.88 \\
\hline & Ulapane et al. model & 1.70 & 1.59 & 1.10 & 1.17 & 2.13 & 2.49 & 2.37 & 1.79 \\
\hline & Saloux et al. model & 2.94 & 2.75 & 1.90 & 1.56 & 3.54 & 3.61 & 3.37 & 2.81 \\
\hline & Mahmoud et al. n.1 model & 2.94 & 2.75 & 1.90 & 1.56 & 3.54 & 6.54 & 13.46 & $\underline{4.67}$ \\
\hline & Averbukh et al. model & 1.70 & 1.59 & 1.10 & 1.17 & 2.13 & $\underline{7.50}$ & 14.26 & $\overline{4.21}$ \\
\hline & Mahmoud et al. n.2 model & 1.83 & 1.98 & 1.34 & 1.24 & 2.42 & $\overline{2.72}$ & $\overline{2.55}$ & 2.01 \\
\hline \multirow{9}{*}{$\begin{array}{l}\text { Sanyo HIT-240 } \\
\text { HDE4 }\end{array}$} & Townsend n.1 model & 1.55 & 1.20 & 2.08 & 3.47 & $\underline{5.81}$ & 4.37 & 3.20 & 3.10 \\
\hline & Townsend n.2 model & 0.93 & 2.08 & 3.02 & 2.95 & $\overline{2.89}$ & 3.00 & 3.05 & 2.56 \\
\hline & Duffie et al. model & 1.29 & 1.06 & 2.13 & 3.35 & 5.33 & 4.13 & 3.10 & 2.91 \\
\hline & Xiao et al. model & $\underline{4.64}$ & $\underline{6.69}$ & $\underline{7.54}$ & $\underline{6.80}$ & 5.68 & 4.61 & 3.65 & 5.66 \\
\hline & Ulapane et al. model & $\overline{1.63}$ & $\overline{1.15}$ & $\overline{2.09}$ & $\overline{3.44}$ & 5.68 & 4.61 & 3.65 & $\overline{3.18}$ \\
\hline & Saloux et al. model & 1.76 & 1.30 & 2.06 & 3.54 & 6.05 & 4.93 & 3.93 & 3.37 \\
\hline & Mahmoud et al. n.1 model & 1.76 & 1.30 & 2.06 & 3.54 & 6.05 & 7.18 & 11.35 & 4.75 \\
\hline & Averbukh et al. model & 1.63 & 1.15 & 2.09 & 3.44 & 5.68 & $\underline{9.09}$ & $\underline{13.25}$ & 5.19 \\
\hline & Mahmoud et al. n.2 model & 1.71 & 1.18 & 2.08 & 3.46 & 5.76 & $\overline{4.68}$ & $\overline{3.71}$ & 3.23 \\
\hline
\end{tabular}

The underline represents the highest value.

Table 6. Percentage ratio of $\operatorname{MAD}(P)$ to the rated maximum power.

The underline represents the highest value of percentage ratio of $\operatorname{MAD}(P)$. 
In the last column the average values of the ratios of $\operatorname{MAD}(I)$ to the current at the issued MPP, and of $\operatorname{MAD}(P)$ to the rated maximum power, calculated for all $I-V$ curves, are listed. For the Kyocera PV panel the smallest $\mathrm{MAD}(I) \mathrm{s}$ range from $0.97 \%$ to $2.71 \%$ of the current at the MPP; the greatest $\mathrm{MAD}(I) \mathrm{s}$ vary from $3.94 \%$ to $15.03 \%$. The smallest MAD $(I)$ s for the Sanyo PV module are in the range $0.92 \%$ to $3.18 \%$ of the current at the MPP; the greatest MAD $(I)$ s range from $4.19 \%$ to $13.13 \%$. The smallest $\operatorname{MAD}(P) \mathrm{s}$ range from $0.97 \%$ to $2.49 \%$ of the rated maximum power for the Kyocera PV panel; the greatest $\operatorname{MAD}(P) \mathrm{s}$ vary from $4.35 \%$ to $14.26 \%$. For the Sanyo PV module the smallest MAD $(P) \mathrm{s}$ are in the range $0.93 \%$ to $3.05 \%$ of the rated maximum power; the greatest $\operatorname{MAD}(P) \mathrm{s}$ vary from $4.64 \%$ to $13.25 \%$. In Tables 7 and 8 the values of $\operatorname{MD}(I)$ and $\operatorname{MD}(P)$ for the analysed panels, calculated considering the $I-V$ curves at a constant cell temperature of $25^{\circ} \mathrm{C}$, are listed.

Table 7. Maximum current differences between the calculated and the issued $I-V$ characteristics of Kyocera KD245GH-4FB2, at temperature $T=25^{\circ} \mathrm{C}$.

\begin{tabular}{|c|c|c|c|c|c|c|}
\hline \multirow{2}{*}{\multicolumn{2}{|c|}{ Parameters at the Maximum Difference Points }} & \multicolumn{5}{|c|}{ Irradiance $\left(\mathrm{W} / \mathrm{m}^{2}\right)$} \\
\hline & & 200 & 400 & 600 & 800 & 1000 \\
\hline \multirow{4}{*}{ Townsend n.1 model } & Voltage (V) & 32.5 & 34.5 & 35.5 & 36.2 & 34.5 \\
\hline & Issued Current (A) & 0.780 & 0.843 & 0.891 & 0.655 & 4.305 \\
\hline & Calculated Current (A) & 0.222 & 0.121 & 0.207 & 0.317 & 4.923 \\
\hline & Difference $(\mathrm{A})$ & -0.558 & -0.722 & -0.684 & -0.338 & 0.618 \\
\hline \multirow{4}{*}{ Townsend n.2 model } & Voltage (V) & 31.0 & 32.5 & 32.0 & 32.5 & 25.0 \\
\hline & Issued Current (A) & 1.211 & 2.165 & 3.967 & 5.093 & 8.653 \\
\hline & Calculated Current (A) & 1.372 & 2.424 & 4.181 & 5.266 & 8.859 \\
\hline & Difference $(\mathrm{A})$ & 0.161 & 0.259 & 0.214 & 0.173 & 0.206 \\
\hline \multirow{4}{*}{ Duffie et al. model } & Voltage (V) & 31.5 & 34.0 & 35.0 & 34.0 & 35.0 \\
\hline & Issued Current (A) & 1.091 & 1.241 & 1.482 & 3.687 & 3.557 \\
\hline & Calculated Current (A) & 0.177 & 0.004 & 0.569 & 4.103 & 4.889 \\
\hline & Difference $(\mathrm{A})$ & -0.914 & -1.237 & -0.913 & 0.416 & $\underline{1.332}$ \\
\hline \multirow{4}{*}{ Xiao et al. model } & Voltage (V) & 34.0 & 35.0 & 35.5 & 35.5 & 34.5 \\
\hline & Issued Current (A) & 0.172 & 0.429 & 0.891 & 1.713 & 4.305 \\
\hline & Calculated Current (A) & 1.222 & 1.808 & 2.058 & 2.619 & 4.786 \\
\hline & Difference $(\mathrm{A})$ & $\underline{1.050}$ & $\underline{1.379}$ & $\underline{1.167}$ & $\underline{0.906}$ & 0.481 \\
\hline \multirow{4}{*}{ Ulapane et al. model } & Voltage (V) & 33.0 & 34.5 & 35.5 & 36.2 & 34.5 \\
\hline & Issued Current (A) & 0.603 & 0.843 & 0.891 & 0.655 & 4.305 \\
\hline & Calculated Current (A) & 0.045 & 0.267 & 0.317 & 0.365 & 4.786 \\
\hline & Difference $(\mathrm{A})$ & -0.558 & -0.576 & -0.574 & -0.290 & 0.481 \\
\hline \multirow{4}{*}{ Saloux et al. model } & Voltage (V) & 32.0 & 34.0 & 35.0 & 36.2 & 35.0 \\
\hline & Issued Current (A) & 0.948 & 1.241 & 1.482 & 0.655 & 3.557 \\
\hline & Calculated Current (A) & 0.273 & 0.449 & 0.870 & 0.214 & 4.434 \\
\hline & Difference (A) & -0.675 & -0.792 & -0.612 & -0.441 & 0.877 \\
\hline \multirow{4}{*}{ Mahmoud et al. n.1 model } & Voltage (V) & 32.0 & 34.0 & 35.0 & 36.2 & 35.0 \\
\hline & Issued Current (A) & 0.948 & 1.241 & 1.482 & 0.655 & 3.557 \\
\hline & Calculated Current (A) & 0.273 & 0.449 & 0.870 & 0.214 & 4.434 \\
\hline & Difference (A) & -0.675 & -0.792 & -0.612 & -0.441 & 0.877 \\
\hline \multirow{4}{*}{ Averbukh et al. model } & Voltage (V) & 33.0 & 34.5 & 35.5 & 36.2 & 34.5 \\
\hline & Issued Current (A) & 0.603 & 0.843 & 0.891 & 0.655 & 4.305 \\
\hline & Calculated Current (A) & 0.045 & 0.267 & 0.317 & 0.365 & 4.786 \\
\hline & Difference (A) & -0.558 & -0.576 & -0.574 & -0.290 & 0.481 \\
\hline \multirow{4}{*}{ Mahmoud et al. n.2 model } & Voltage (V) & 32.5 & 34.5 & 35.5 & 36.2 & 34.5 \\
\hline & Issued Current (A) & 0.780 & 0.843 & 0.891 & 0.655 & 4.305 \\
\hline & Calculated Current (A) & 0.274 & 0.180 & 0.251 & 0.337 & 4.870 \\
\hline & Difference (A) & -0.506 & -0.663 & -0.640 & -0.318 & 0.565 \\
\hline
\end{tabular}

The underline represents the highest value of maximum current differences for each irradiance. 
Table 8. Maximum current differences between the calculated and the issued $I-V$ characteristics of Sanyo HIT-240 HDE4, at temperature $T=25^{\circ} \mathrm{C}$.

\begin{tabular}{|c|c|c|c|c|c|c|}
\hline \multirow{2}{*}{\multicolumn{2}{|c|}{ Parameters at the Maximum Difference Points }} & \multicolumn{5}{|c|}{ Irradiance $\left(\mathrm{W} / \mathrm{m}^{2}\right)$} \\
\hline & & 200 & 400 & 600 & 800 & 1000 \\
\hline \multirow{4}{*}{ Townsend n.1 model } & Voltage (V) & 38.2 & 40.6 & 39.1 & 40.3 & 40.6 \\
\hline & Issued Current (A) & 0.548 & 0.554 & 2.171 & 2.458 & 3.233 \\
\hline & Calculated Current (A) & 0.152 & 0.086 & 2.594 & 3.207 & 4.409 \\
\hline & Difference (A) & -0.396 & -0.468 & 0.423 & 0.749 & 1.176 \\
\hline \multirow{4}{*}{ Townsend n.2 model } & Voltage (V) & 36.7 & 38.5 & 39.1 & 39.1 & 39.7 \\
\hline & Issued Current (A) & 0.833 & 1.414 & 2.171 & 3.350 & 4.018 \\
\hline & Calculated Current (A) & 1.043 & 1.877 & 2.816 & 3.982 & 4.628 \\
\hline & Difference $(\mathrm{A})$ & 0.210 & 0.463 & 0.645 & 0.632 & 0.610 \\
\hline \multirow{4}{*}{ Duffie et al. model } & Voltage (V) & 38.5 & 40.6 & 39.1 & 40.3 & 40.6 \\
\hline & Issued Current (A) & 0.471 & 0.554 & 2.171 & 2.458 & 3.233 \\
\hline & Calculated Current (A) & 0.096 & 0.198 & 2.628 & 3.187 & 4.317 \\
\hline & Difference $(\mathrm{A})$ & -0.375 & -0.356 & 0.457 & 0.729 & 1.084 \\
\hline \multirow{4}{*}{ Xiao et al. model } & Voltage (V) & 40.3 & 41.5 & 40.9 & 40.9 & 40.6 \\
\hline & Issued Current (A) & 0.063 & 0.132 & 1.076 & 1.976 & 3.233 \\
\hline & Calculated Current (A) & 0.951 & 1.399 & 2.479 & 3.280 & 4.383 \\
\hline & Difference $(\mathrm{A})$ & $\underline{0.888}$ & $\underline{1.267}$ & $\underline{1.403}$ & $\underline{1.304}$ & 1.150 \\
\hline \multirow{4}{*}{ Ulapane et al. model } & Voltage (V) & 38.5 & 40.6 & 39.1 & 40.3 & 40.6 \\
\hline & Issued Current (A) & 0.471 & 0.554 & 2.171 & 2.458 & 3.233 \\
\hline & Calculated Current (A) & 0.022 & 0.119 & 2.604 & 3.202 & 4.383 \\
\hline & Difference $(\mathrm{A})$ & -0.449 & -0.435 & 0.433 & 0.744 & 1.150 \\
\hline \multirow{4}{*}{ Saloux et al. model } & Voltage (V) & 38.2 & 40.6 & 39.1 & 40.3 & 40.6 \\
\hline & Issued Current (A) & 0.548 & 0.554 & 2.171 & 2.458 & 3.233 \\
\hline & Calculated Current (A) & 0.104 & 0.032 & 2.577 & 3.217 & 4.454 \\
\hline & Difference $(\mathrm{A})$ & -0.444 & -0.522 & 0.406 & 0.759 & $\underline{1.221}$ \\
\hline \multirow{4}{*}{ Mahmoud et al. n.1 model } & Voltage (V) & 38.2 & 40.6 & 39.1 & 40.3 & 40.6 \\
\hline & Issued Current (A) & 0.548 & 0.554 & 2.171 & 2.458 & 3.233 \\
\hline & Calculated Current (A) & 0.104 & 0.032 & 2.577 & 3.217 & 4.454 \\
\hline & Difference $(\mathrm{A})$ & -0.444 & -0.522 & 0.406 & 0.759 & $\underline{1.221}$ \\
\hline \multirow{4}{*}{ Averbukh et al. model } & Voltage (V) & 38.5 & 40.6 & 39.1 & 40.3 & 40.6 \\
\hline & Issued Current (A) & 0.471 & 0.554 & 2.171 & 2.458 & 3.233 \\
\hline & Calculated Current (A) & 0.022 & 0.119 & 2.604 & 3.202 & 4.383 \\
\hline & Difference (A) & -0.449 & -0.435 & 0.433 & 0.744 & 1.150 \\
\hline \multirow{4}{*}{ Mahmoud et al. n.2 model } & Voltage (V) & 38.5 & 40.6 & 39.1 & 40.3 & 40.6 \\
\hline & Issued Current (A) & 0.471 & 0.554 & 2.171 & 2.458 & 3.233 \\
\hline & Calculated Current (A) & 0.004 & 0.099 & 2.597 & 3.206 & 4.399 \\
\hline & Difference $(\mathrm{A})$ & -0.467 & -0.455 & 0.426 & 0.748 & 1.166 \\
\hline
\end{tabular}

The underline represents the highest value of maximum current differences for each irradiance.

Considering the $I-V$ curves at constant temperature of the Kyocera PV panel, the Townsend n.2 model seems to be the most accurate; the $\mathrm{MD}(I) \mathrm{s}$ vary from $0.161 \mathrm{~A}$ to $0.259 \mathrm{~A}$. The greatest current differences, which are contained in the range from $0.906 \mathrm{~A}$ to $1.379 \mathrm{~A}$, are observed for the Duffie et al. and the Xiao et al. model. The smallest $\mathrm{MD}(I) \mathrm{s}$ result for the Sanyo PV module by using the Townsend $\mathrm{n} .2$, the Duffie et al. the Saloux et al. and the Mahmoud et al. n.1 models. These differences are in the range -0.356 to $0.632 \mathrm{~A}$. The greatest inaccuracies derive from the Xiao et al., the Saloux et al. and the Mahmoud et al. n.1 models. For these models differences varying between $0.888 \mathrm{~A}$ and $1.403 \mathrm{~A}$ were calculated. Tables 9 and 10 list the MD(I)s calculated for Kyocera KD245GH-4FB2 and Sanyo HIT-240 HDE4 PV panels at a constant solar irradiance of $1000 \mathrm{~W} / \mathrm{m}^{2}$. 
Table 9. Maximum current differences between the calculated and the issued $I-V$ characteristics of Kyocera KD245GH-4FB2, at irradiance $G=1000 \mathrm{~W} / \mathrm{m}^{2}$.

\begin{tabular}{|c|c|c|c|c|}
\hline \multicolumn{2}{|c|}{ Parameters at the Maximum Difference Points } & \multicolumn{3}{|c|}{ Temperature $\left({ }^{\circ} \mathrm{C}\right)$} \\
\hline 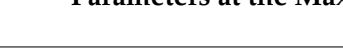 & 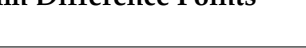 & 25 & 50 & 75 \\
\hline \multirow{4}{*}{ Townsend n.1 model } & Voltage (V) & 34.5 & 31.5 & 28.0 \\
\hline & Issued Current (A) & 4.305 & 3.593 & 3.589 \\
\hline & Calculated Current (A) & 4.923 & 4.502 & 4.741 \\
\hline & Difference $(\mathrm{A})$ & 0.618 & 0.909 & 1.152 \\
\hline \multirow{4}{*}{ Townsend n.2 model } & Voltage (V) & 25.0 & 33.6 & 29.5 \\
\hline & Issued Current (A) & 8.653 & 0.000 & 1.326 \\
\hline & Calculated Current (A) & 8.859 & 0.598 & 2.447 \\
\hline & Difference $(\mathrm{A})$ & 0.206 & 0.598 & 1.121 \\
\hline \multirow{4}{*}{ Duffie et al. model } & Voltage (V) & 35.0 & 31.5 & 28.0 \\
\hline & Issued Current (A) & 3.557 & 3.593 & 3.589 \\
\hline & Calculated Current (A) & 4.889 & 4.897 & 4.840 \\
\hline & Difference $(\mathrm{A})$ & $\underline{1.332}$ & 1.304 & 1.251 \\
\hline \multirow{4}{*}{ Xiao et al. model } & Voltage (V) & 34.5 & 31.0 & 27.5 \\
\hline & Issued Current (A) & 4.305 & 4.278 & 4.241 \\
\hline & Calculated Current (A) & 4.786 & 4.894 & 4.997 \\
\hline & Difference $(\mathrm{A})$ & 0.481 & 0.616 & 0.756 \\
\hline \multirow{4}{*}{ Ulapane et al. model } & Voltage (V) & 34.5 & 31.0 & 27.5 \\
\hline & Issued Current (A) & 4.305 & 4.278 & 4.241 \\
\hline & Calculated Current (A) & 4.786 & 4.894 & 4.996 \\
\hline & Difference $(\mathrm{A})$ & 0.481 & 0.616 & 0.755 \\
\hline \multirow{4}{*}{ Saloux et al. model } & Voltage (V) & 35.0 & 31.0 & 28.0 \\
\hline & Issued Current (A) & 3.557 & 4.278 & 3.589 \\
\hline & Calculated Current (A) & 4.434 & 5.234 & 4.650 \\
\hline & Difference (A) & 0.877 & 0.956 & 1.061 \\
\hline \multirow{4}{*}{ Mahmoud et al. n.1 model } & Voltage (V) & 35.00 & 32.00 & 29.00 \\
\hline & Issued Current (A) & 3.557 & 2.829 & 2.122 \\
\hline & Calculated Current (A) & 4.434 & 4.411 & 5.078 \\
\hline & Difference $(\mathrm{A})$ & 0.877 & 1.582 & 2.956 \\
\hline \multirow{4}{*}{ Averbukh et al. model } & Voltage (V) & 34.5 & 33.0 & 30.2 \\
\hline & Issued Current (A) & 4.305 & 1.125 & 0.165 \\
\hline & Calculated Current (A) & 4.786 & 2.981 & 3.370 \\
\hline & Difference (A) & 0.481 & $\underline{1.856}$ & $\underline{3.205}$ \\
\hline \multirow{4}{*}{ Mahmoud et al. n.2 model } & Voltage (V) & 34.5 & 31.0 & 27.5 \\
\hline & Issued Current (A) & 4.305 & 4.278 & 4.241 \\
\hline & Calculated Current (A) & 4.870 & 4.967 & 5.060 \\
\hline & Difference (A) & 0.565 & 0.689 & 0.819 \\
\hline
\end{tabular}

The underline represents the highest value of maximum current differences for each temperature.

Table 10. Maximum current differences between the calculated and the issued $I-V$ characteristics of Sanyo HIT-240 HDE4, at irradiance $G=1000 \mathrm{~W} / \mathrm{m}^{2}$.

\begin{tabular}{ccccc}
\hline \multirow{2}{*}{ Parameters at the Maximum Difference Points } & \multicolumn{3}{c}{ Temperature $\left({ }^{\circ} \mathbf{C}\right)$} \\
\cline { 3 - 5 } & & $\mathbf{2 5}$ & $\mathbf{5 0}$ & $\mathbf{7 5}$ \\
\hline \multirow{2}{*}{ Townsend n.1 model } & Voltage (V) & 40.6 & 38.2 & 35.5 \\
& Issued Current (A) & 3.233 & 2.981 & 2.984 \\
& Calculated Current (A) & 4.409 & 3.901 & 3.545 \\
& Difference (A) & 1.176 & 0.920 & 0.561 \\
\hline \multirow{2}{*}{ Townsend n.2 model } & Voltage (V) & 39.7 & 38.2 & 36.1 \\
& Issued Current (A) & 4.018 & 2.981 & 2.366 \\
& Calculated Current (A) & 4.628 & 3.576 & 2.897 \\
& Difference (A) & 0.610 & 0.595 & 0.531 \\
\hline Duffie et al. model & Voltage (V) & 40.6 & 38.2 & 35.5 \\
& Issued Current (A) & 3.233 & 2.981 & 2.984 \\
& Calculated Current (A) & 4.317 & 3.848 & 3.539 \\
& Difference (A) & 1.084 & 0.867 & 0.555
\end{tabular}


Table 10. Cont.

\begin{tabular}{|c|c|c|c|c|}
\hline \multirow{2}{*}{\multicolumn{2}{|c|}{ Parameters at the Maximum Difference Points }} & \multicolumn{3}{|c|}{ Temperature $\left({ }^{\circ} \mathrm{C}\right)$} \\
\hline & & 25 & 50 & 75 \\
\hline \multirow{4}{*}{ Xiao et al. model } & Voltage $(\mathrm{V})$ & 40.6 & 38.2 & 35.5 \\
\hline & Issued Current (A) & 3.233 & 2.981 & 2.984 \\
\hline & Calculated Current (A) & 4.383 & 3.940 & 3.712 \\
\hline & Difference $(\mathrm{A})$ & 1.150 & 0.959 & 0.728 \\
\hline \multirow{4}{*}{ Ulapane et al. model } & Voltage $(\mathrm{V})$ & 40.6 & 38.2 & 35.5 \\
\hline & Issued Current (A) & 3.233 & 2.981 & 2.984 \\
\hline & Calculated Current (A) & 4.383 & 3.940 & 3.712 \\
\hline & Difference $(\mathrm{A})$ & 1.150 & 0.959 & 0.728 \\
\hline \multirow{4}{*}{ Saloux et al. model } & Voltage $(\mathrm{V})$ & 40.6 & 38.2 & 35.5 \\
\hline & Issued Current (A) & 3.233 & 2.981 & 2.984 \\
\hline & Calculated Current (A) & 4.454 & 4.008 & 3.773 \\
\hline & Difference (A) & $\underline{1.221}$ & 1.027 & 0.789 \\
\hline \multirow{4}{*}{ Mahmoud et al. n.1 model } & Voltage $(\mathrm{V})$ & 40.6 & 38.2 & 36.1 \\
\hline & Issued Current (A) & 3.233 & 2.981 & 2.366 \\
\hline & Calculated Current (A) & 4.454 & 4.425 & 4.362 \\
\hline & Difference $(\mathrm{A})$ & $\underline{1.221}$ & 1.444 & 1.996 \\
\hline \multirow{4}{*}{ Averbukh et al. model } & Voltage $(\mathrm{V})$ & 40.6 & 39.1 & 38.2 \\
\hline & Issued Current (A) & 3.233 & 2.046 & 0.000 \\
\hline & Calculated Current (A) & 4.383 & 3.738 & 2.429 \\
\hline & Difference (A) & 1.150 & $\underline{1.692}$ & 2.429 \\
\hline \multirow{4}{*}{ Mahmoud et al. n.2 model } & Voltage (V) & 40.6 & 38.2 & 35.5 \\
\hline & Issued Current (A) & 3.233 & 2.981 & 2.984 \\
\hline & Calculated Current (A) & 4.399 & 3.955 & 3.726 \\
\hline & Difference (A) & 1.166 & 0.974 & 0.742 \\
\hline
\end{tabular}

The underline represents the highest value of maximum current differences for each temperature.

The smallest $\mathrm{MD}(I)$ s for the Kyocera PV module at constant solar irradiance are obtained by adopting the Townsend n.2 and the Ulapane et al. models. Such differences range from $0.206 \mathrm{~A}$ to $0.775 \mathrm{~A}$. The greatest inaccuracies derive from the Duffie et al. and the Averbukh et al. models, for which differences varying between $1.332 \mathrm{~A}$ and $3.205 \mathrm{~A}$ are noted. The Townsend n.2 model seems to be the most accurate for the Sanyo PV panel; the $\mathrm{MD}(I)$ s vary from $0.531 \mathrm{~A}$ to $0.610 \mathrm{~A}$. The greatest current differences, which are contained in the range from $1.221 \mathrm{~A}$ to $2.429 \mathrm{~A}$, are provided by the Averbukh et al. the Saloux et al. and the Mahmoud et al. n.1 models. Tables 11-14 show the effectiveness of the analysed models to predict the power generated by PV modules.

Table 11. Maximum power differences between the calculated and the issued $I-V$ characteristics of Kyocera KD245GH-4FB2, at temperature $T=25^{\circ} \mathrm{C}$.

\begin{tabular}{|c|c|c|c|c|c|c|}
\hline \multirow{2}{*}{\multicolumn{2}{|c|}{ Parameters at the Maximum Difference Points }} & \multicolumn{5}{|c|}{ Irradiance $\left(\mathrm{W} / \mathrm{m}^{2}\right)$} \\
\hline & & 200 & 400 & 600 & 800 & 1000 \\
\hline \multirow{4}{*}{ Townsend n.1 model } & Voltage (V) & 32.5 & 34.5 & 35.5 & 36.2 & 34.5 \\
\hline & Issued Power $(\mathrm{W})$ & 25.34 & 29.07 & 31.65 & 23.70 & 148.52 \\
\hline & Calculated Power (W) & 7.22 & 4.16 & 7.35 & 11.47 & 169.85 \\
\hline & Difference $(\mathrm{W})$ & -18.12 & -24.91 & -24.30 & -12.23 & 21.33 \\
\hline \multirow{4}{*}{ Townsend n.2 model } & Voltage (V) & 31.5 & 32.5 & 32.0 & 32.5 & 34.4 \\
\hline & Issued Power (W) & 34.38 & 70.37 & 126.94 & 165.51 & 154.25 \\
\hline & Calculated Power (W) & 39.41 & 78.78 & 133.79 & 171.15 & 148.41 \\
\hline & Difference $(W)$ & 5.03 & 8.41 & 6.85 & 5.64 & -5.84 \\
\hline \multirow{4}{*}{ Duffie et al. model } & Voltage (V) & 31.5 & 34.0 & 35.0 & 34.5 & 35.0 \\
\hline & Issued Power $(\mathrm{W})$ & 34.38 & 42.18 & 51.85 & 106.41 & 124.50 \\
\hline & Calculated Power (W) & 5.57 & 0.14 & 19.92 & 120.73 & 171.11 \\
\hline & Difference $(W)$ & -28.81 & -42.04 & -31.93 & 14.32 & $\underline{46.61}$ \\
\hline
\end{tabular}


Table 11. Cont.

\begin{tabular}{|c|c|c|c|c|c|c|}
\hline \multirow{2}{*}{\multicolumn{2}{|c|}{ Parameters at the Maximum Difference Points }} & \multicolumn{5}{|c|}{ Irradiance $\left(\mathrm{W} / \mathrm{m}^{2}\right)$} \\
\hline & & 200 & 400 & 600 & 800 & 1000 \\
\hline \multirow{4}{*}{ Xiao et al. model } & Voltage $(\mathrm{V})$ & 34.0 & 35.0 & 36.0 & 35.5 & 34.5 \\
\hline & Issued Power (W) & 5.86 & 15.00 & 9.53 & 60.81 & 148.52 \\
\hline & Calculated Power (W) & 41.56 & 63.28 & 50.96 & 92.96 & 165.12 \\
\hline & Difference $(\mathrm{W})$ & $\underline{35.70}$ & $\underline{48.28}$ & $\underline{41.43}$ & $\underline{32.15}$ & 16.60 \\
\hline \multirow{4}{*}{ Ulapane et al. model } & Voltage $(\mathrm{V})$ & 33.0 & 34.5 & 35.5 & 36.2 & 34.5 \\
\hline & Issued Power (W) & 19.91 & 29.07 & 31.65 & 23.70 & 148.52 \\
\hline & Calculated Power (W) & 1.49 & 9.23 & 11.25 & 13.21 & 165.12 \\
\hline & Difference $(\mathrm{W})$ & -18.42 & -19.84 & -20.40 & -10.49 & 16.60 \\
\hline \multirow{4}{*}{ Saloux et al. model } & Voltage $(\mathrm{V})$ & 32.0 & 34.0 & 35.0 & 36.2 & 35.0 \\
\hline & Issued Power $(\mathrm{W})$ & 30.34 & 42.18 & 51.85 & 23.70 & 124.50 \\
\hline & Calculated Power (W) & 8.73 & 15.26 & 30.46 & 7.76 & 155.20 \\
\hline & Difference $(\mathrm{W})$ & -21.61 & -26.92 & -21.39 & -15.94 & 30.70 \\
\hline \multirow{4}{*}{ Mahmoud et al. n.1 model } & Voltage $(\mathrm{V})$ & 32.0 & 34.0 & 35.0 & 36.2 & 35.0 \\
\hline & Issued Power (W) & 30.34 & 42.18 & 51.85 & 23.70 & 124.50 \\
\hline & Calculated Power (W) & 8.73 & 15.26 & 30.46 & 7.75 & 155.20 \\
\hline & Difference $(\mathrm{W})$ & -21.61 & -26.92 & -21.39 & -15.95 & 30.70 \\
\hline \multirow{4}{*}{ Averbukh et al. model } & Voltage (V) & 33.0 & 34.5 & 35.5 & 36.2 & 34.5 \\
\hline & Issued Power (W) & 19.91 & 29.07 & 31.65 & 23.70 & 148.52 \\
\hline & Calculated Power (W) & 1.49 & 9.23 & 11.25 & 13.21 & 165.12 \\
\hline & Difference $(\mathrm{W})$ & -18.42 & -19.84 & -20.40 & -10.49 & 16.60 \\
\hline \multirow{4}{*}{ Mahmoud et al. n.2 model } & Voltage (V) & 32.5 & 34.5 & 35.5 & 36.2 & 34.5 \\
\hline & Issued Power (W) & 25.34 & 29.07 & 31.65 & 23.70 & 148.52 \\
\hline & Calculated Power (W) & 8.92 & 6.20 & 8.91 & 12.22 & 168.00 \\
\hline & Difference $(\mathrm{W})$ & -16.42 & -22.87 & -22.74 & -11.48 & 19.48 \\
\hline
\end{tabular}

The underline represents the highest value of maximum current differences for each irradiance.

Table 12. Maximum power differences between the calculated and the issued $I-V$ characteristics of Sanyo HIT-240 HDE4, at temperature $T=25^{\circ} \mathrm{C}$.

\begin{tabular}{|c|c|c|c|c|c|c|}
\hline \multirow{2}{*}{\multicolumn{2}{|c|}{ Parameters at the Maximum Difference Points }} & \multicolumn{5}{|c|}{ Irradiance $\left(\mathrm{W} / \mathrm{m}^{2}\right)$} \\
\hline & & 200 & 400 & 600 & 800 & 1000 \\
\hline \multirow{4}{*}{ Townsend n.1 model } & Voltage (V) & 38.2 & 40.6 & 39.1 & 40.3 & 40.9 \\
\hline & Issued Power $(\mathrm{W})$ & 20.93 & 22.48 & 84.96 & 99.14 & 119.63 \\
\hline & Calculated Power (W) & 5.81 & 3.51 & 101.50 & 129.35 & 167.61 \\
\hline & Difference $(\mathrm{W})$ & -15.12 & -18.97 & 16.54 & 30.21 & 47.98 \\
\hline \multirow{4}{*}{ Townsend n.2 model } & Voltage (V) & 36.7 & 38.5 & 39.1 & 39.7 & 39.7 \\
\hline & Issued Power (W) & 30.59 & 54.47 & 84.96 & 116.58 & 159.62 \\
\hline & Calculated Power (W) & 38.28 & 72.30 & 110.19 & 141.48 & 183.88 \\
\hline & Difference $(W)$ & 7.69 & 17.83 & 25.23 & 24.90 & 24.26 \\
\hline \multirow{4}{*}{ Duffie et al. model } & Voltage (V) & 38.5 & 40.6 & 39.1 & 40.3 & 40.6 \\
\hline & Issued Power (W) & 18.13 & 22.48 & 84.96 & 99.14 & 131.28 \\
\hline & Calculated Power (W) & 3.70 & 8.02 & 102.84 & 128.52 & 175.29 \\
\hline & Difference $(W)$ & -14.43 & -14.46 & 17.88 & 29.38 & 44.01 \\
\hline \multirow{4}{*}{ Xiao et al. model } & Voltage (V) & 40.3 & 41.5 & 41.5 & 40.9 & 40.9 \\
\hline & Issued Power (W) & 2.54 & 5.48 & 28.49 & 80.90 & 119.63 \\
\hline & Calculated Power (W) & 38.34 & 58.12 & 86.32 & 134.26 & 166.43 \\
\hline & Difference $(W)$ & $\underline{35.80}$ & $\underline{52.64}$ & $\underline{57.83}$ & $\underline{53.36}$ & 46.80 \\
\hline \multirow{4}{*}{ Ulapane et al. model } & Voltage (V) & 38.5 & 40.6 & 39.1 & 40.3 & 40.9 \\
\hline & Issued Power (W) & 18.13 & 22.48 & 84.96 & 99.14 & 119.63 \\
\hline & Calculated Power (W) & 0.85 & 4.85 & 101.87 & 129.13 & 166.43 \\
\hline & Difference $(\mathrm{W})$ & -17.28 & -17.63 & 16.91 & 29.99 & 46.80 \\
\hline \multirow{4}{*}{ Saloux et al. model } & Voltage (V) & 38.2 & 40.6 & 39.1 & 40.3 & 40.9 \\
\hline & Issued Power (W) & 20.93 & 22.48 & 84.96 & 99.14 & 119.63 \\
\hline & Calculated Power (W) & 3.98 & 1.29 & 100.83 & 129.76 & 169.57 \\
\hline & Difference $(W)$ & -16.95 & -21.19 & 15.87 & 30.62 & $\underline{49.94}$ \\
\hline
\end{tabular}


Table 12. Cont.

\begin{tabular}{|c|c|c|c|c|c|c|}
\hline \multirow{2}{*}{\multicolumn{2}{|c|}{ Parameters at the Maximum Difference Points }} & \multicolumn{5}{|c|}{ Irradiance $\left(\mathrm{W} / \mathrm{m}^{2}\right)$} \\
\hline & & 200 & 400 & 600 & 800 & 1000 \\
\hline \multirow{4}{*}{ Mahmoud et al. n.1 model } & Voltage $(\mathrm{V})$ & 38.2 & 40.6 & 39.1 & 40.3 & 40.9 \\
\hline & Issued Power $(\mathrm{W})$ & 20.93 & 22.48 & 84.96 & 99.14 & 119.63 \\
\hline & Calculated Power (W) & 3.98 & 1.29 & 100.83 & 129.76 & 169.57 \\
\hline & Difference $(\mathrm{W})$ & -16.95 & -21.19 & 15.87 & 30.62 & $\underline{49.94}$ \\
\hline \multirow{4}{*}{ Averbukh et al. model } & Voltage (V) & 38.5 & 40.6 & 39.1 & 40.3 & 40.9 \\
\hline & Issued Power (W) & 18.13 & 22.48 & 84.96 & 99.14 & 119.63 \\
\hline & Calculated Power (W) & 0.85 & 4.85 & 101.87 & 129.13 & 166.43 \\
\hline & Difference $(\mathrm{W})$ & -17.28 & -17.63 & 16.91 & 29.99 & 46.80 \\
\hline \multirow{4}{*}{ Mahmoud et al. n. 2 model } & Voltage (V) & 38.5 & 40.6 & 39.1 & 40.3 & 40.9 \\
\hline & Issued Power (W) & 18.13 & 22.48 & 84.96 & 99.14 & 119.63 \\
\hline & Calculated Power (W) & 0.16 & 4.01 & 101.60 & 129.29 & 167.16 \\
\hline & Difference $(W)$ & -17.97 & -18.47 & 16.64 & 30.15 & 47.53 \\
\hline
\end{tabular}

The underline represents the highest value of maximum current differences for each irradiance.

For the Kyocera PV panel, the smallest $\mathrm{MD}(P)$ s at constant cell temperature are again ascribed to the Townsend $\mathrm{n} .2$ model that yields values varying from $-5.84 \mathrm{~W}$ to $8.41 \mathrm{~W}$. The greatest $\mathrm{MD}(P) \mathrm{s}$, which occur with the Xiao et al. and the Duffie et al. models, are in the range $32.15 \mathrm{~W}$ to $48.28 \mathrm{~W}$. For the Sanyo PV module, the smallest $\mathrm{MD}(P) \mathrm{s}$ at constant temperature, which vary from $-14.46 \mathrm{~W}$ to $24.90 \mathrm{~W}$, are obtained by means of the Townsend n.2, the Duffie et al. the Saloux et al. and the Mahmoud et al. n.1 models. The Xiao et al., the Saloux et al. and the Mahmoud et al. n.1 models yield the greatest inaccuracies, which vary from $35.80 \mathrm{~W}$ to $57.83 \mathrm{~W}$.

Table 13. Maximum power differences between the calculated and the issued $I-V$ characteristics of Kyocera KD245GH-4FB2, at irradiance $G=1000 \mathrm{~W} / \mathrm{m}^{2}$.

\begin{tabular}{|c|c|c|c|c|}
\hline \multirow{2}{*}{\multicolumn{2}{|c|}{ Parameters at the Maximum Difference Points }} & \multicolumn{3}{|c|}{ Temperature $\left({ }^{\circ} \mathrm{C}\right)$} \\
\hline & in Dinference romts & 25 & 50 & 75 \\
\hline \multirow{4}{*}{ Townsend n.1 model } & Voltage (V) & 34.5 & 31.5 & 28.5 \\
\hline & Issued Power $(\mathrm{W})$ & 148.52 & 113.18 & 81.94 \\
\hline & Calculated Power (W) & 169.85 & 141.81 & 114.70 \\
\hline & Difference $(\mathrm{W})$ & 21.33 & 28.63 & 32.76 \\
\hline \multirow{4}{*}{ Townsend n.2 model } & Voltage $(\mathrm{V})$ & 34.4 & 33.6 & 30.2 \\
\hline & Issued Power (W) & 154.25 & 0.00 & 4.98 \\
\hline & Calculated Power (W) & 148.41 & 20.08 & 38.28 \\
\hline & Difference $(W)$ & -5.84 & 20.08 & 33.30 \\
\hline \multirow{4}{*}{ Duffie et al. model } & Voltage (V) & 35.0 & 31.5 & 28.0 \\
\hline & Issued Power $(\mathrm{W})$ & 124.50 & 113.18 & 100.49 \\
\hline & Calculated Power (W) & 171.11 & 154.26 & 135.51 \\
\hline & Difference $(\mathrm{W})$ & $\underline{46.61}$ & 41.08 & 35.02 \\
\hline \multirow{4}{*}{ Xiao et al. model } & Voltage (V) & 34.5 & 31.0 & 27.5 \\
\hline & Issued Power (W) & 148.52 & 132.62 & 116.63 \\
\hline & Calculated Power (W) & 165.12 & 151.73 & 137.42 \\
\hline & Difference $(W)$ & 16.60 & 19.11 & 20.79 \\
\hline \multirow{4}{*}{ Ulapane et al. model } & Voltage (V) & 34.5 & 31.0 & 27.5 \\
\hline & Issued Power $(W)$ & 148.52 & 132.62 & 116.63 \\
\hline & Calculated Power (W) & 165.12 & 151.73 & 137.39 \\
\hline & Difference $(\mathrm{W})$ & 16.60 & 19.11 & 20.76 \\
\hline \multirow{4}{*}{ Saloux et al. model } & Voltage (V) & 35.0 & 31.5 & 28.0 \\
\hline & Issued Power $(W)$ & 124.50 & 113.18 & 100.49 \\
\hline & Calculated Power (W) & 155.20 & 143.21 & 130.21 \\
\hline & Difference $(W)$ & 30.70 & 30.03 & 29.72 \\
\hline \multirow{4}{*}{ Mahmoud et al. n.1 model } & Voltage (V) & 35.0 & 32.0 & 29.5 \\
\hline & Issued Power $(W)$ & 124.50 & 90.53 & 39.12 \\
\hline & Calculated Power (W) & 155.20 & 141.16 & 126.15 \\
\hline & Difference $(W)$ & 30.70 & 50.63 & 87.03 \\
\hline
\end{tabular}


Table 13. Cont.

\begin{tabular}{ccccc}
\hline \multirow{2}{*}{ Parameters at the Maximum Difference Points } & \multicolumn{3}{c}{ Temperature $\left({ }^{\circ} \mathbf{C}\right)$} \\
\cline { 3 - 5 } & & $\mathbf{2 5}$ & $\mathbf{5 0}$ & $\mathbf{7 5}$ \\
\hline \multirow{3}{*}{ Averbukh et al. model } & Voltage (V) & 34.5 & 33.0 & 30.3 \\
& Issued Power (W) & 148.52 & 37.13 & 0.00 \\
& Calculated Power (W) & 165.12 & 98.37 & 97.01 \\
& Difference (W) & 16.60 & $\underline{61.24}$ & 97.01 \\
\hline \multirow{3}{*}{ Mahmoud et al. n.2 model } & Voltage (V) & 34.5 & 31.0 & 27.5 \\
& Issued Power (W) & 148.52 & 132.62 & 116.63 \\
& Calculated Power (W) & 168.00 & 153.98 & 139.16 \\
& Difference (W) & 19.48 & 21.36 & 22.53 \\
\hline
\end{tabular}

The underline represents the highest value of maximum current differences for each temperature.

Table 14. Maximum power differences between the calculated and the issued $I-V$ characteristics of Sanyo HIT-240 HDE4, at irradiance $G=1000 \mathrm{~W} / \mathrm{m}^{2}$.

\begin{tabular}{|c|c|c|c|c|}
\hline \multirow{2}{*}{\multicolumn{2}{|c|}{ Parameters at the Maximum Difference Points }} & \multicolumn{3}{|c|}{ Temperature $\left({ }^{\circ} \mathrm{C}\right)$} \\
\hline & & 25 & 50 & 75 \\
\hline \multirow{4}{*}{ Townsend n.1 model } & Voltage $(\mathrm{V})$ & 40.9 & 38.2 & 35.5 \\
\hline & Issued Power $(\mathrm{W})$ & 119.63 & 113.78 & 105.97 \\
\hline & Calculated Power (W) & 167.61 & 148.89 & 125.89 \\
\hline & Difference $(\mathrm{W})$ & 47.98 & 35.11 & 19.92 \\
\hline \multirow{4}{*}{ Townsend n.2 model } & Voltage (V) & 39.7 & 38.2 & 36.1 \\
\hline & Issued Power (W) & 159.62 & 113.78 & 85.45 \\
\hline & Calculated Power (W) & 183.88 & 136.48 & 104.64 \\
\hline & Difference $(\mathrm{W})$ & 24.26 & 22.70 & 19.19 \\
\hline \multirow{4}{*}{ Duffie et al. model } & Voltage $(\mathrm{V})$ & 40.6 & 38.2 & 35.5 \\
\hline & Issued Power (W) & 131.28 & 113.78 & 105.97 \\
\hline & Calculated Power (W) & 175.29 & 146.85 & 125.69 \\
\hline & Difference $(\mathrm{W})$ & 44.01 & 33.07 & 19.72 \\
\hline \multirow{4}{*}{ Xiao et al. model } & Voltage (V) & 40.9 & 38.2 & 35.5 \\
\hline & Issued Power (W) & 119.63 & 113.78 & 105.97 \\
\hline & Calculated Power (W) & 166.43 & 150.36 & 131.83 \\
\hline & Difference $(W)$ & 46.80 & 36.58 & 25.86 \\
\hline \multirow{4}{*}{ Ulapane et al. model } & Voltage $(\mathrm{V})$ & 40.9 & 38.2 & 35.5 \\
\hline & Issued Power (W) & 119.63 & 113.78 & 105.97 \\
\hline & Calculated Power (W) & 166.43 & 150.36 & 131.83 \\
\hline & Difference $(\mathrm{W})$ & 46.80 & 36.58 & 25.86 \\
\hline \multirow{4}{*}{ Saloux et al. model } & Voltage (V) & 40.9 & 38.2 & 35.5 \\
\hline & Issued Power (W) & 119.63 & 113.78 & 105.97 \\
\hline & Calculated Power (W) & 169.57 & 152.96 & 134.01 \\
\hline & Difference $(\mathrm{W})$ & $\underline{49.94}$ & 39.18 & 28.04 \\
\hline \multirow{4}{*}{ Mahmoud et al. n.1 model } & Voltage (V) & 40.9 & 38.2 & 36.1 \\
\hline & Issued Power (W) & 119.63 & 113.78 & 85.45 \\
\hline & Calculated Power (W) & 169.57 & 168.87 & 157.54 \\
\hline & Difference $(\mathrm{W})$ & $\underline{49.94}$ & 55.09 & 72.09 \\
\hline \multirow{4}{*}{ Averbukh et al. model } & Voltage $(\mathrm{V})$ & 40.9 & 39.1 & 38.2 \\
\hline & Issued Power (W) & 119.63 & 80.06 & 0.00 \\
\hline & Calculated Power (W) & 166.43 & 146.26 & 92.72 \\
\hline & Difference $(\mathrm{W})$ & 46.80 & $\underline{66.20}$ & $\underline{92.72}$ \\
\hline \multirow{4}{*}{ Mahmoud et al. n.2 model } & Voltage $(\mathrm{V})$ & 40.9 & 38.2 & 35.5 \\
\hline & Issued Power (W) & 119.63 & 113.78 & 105.97 \\
\hline & Calculated Power (W) & 167.16 & 150.93 & 132.32 \\
\hline & Difference $(W)$ & 47.53 & 37.15 & 26.35 \\
\hline
\end{tabular}

The underline represents the highest value of maximum current differences for each temperature.

Considering the $\mathrm{MD}(P)$ s at constant solar irradiance, the smallest values for the Kyocera PV panel are obtained by means of the Townsend n.2, the Xiao et al. and the Ulapane et al. models. The differences range $-5.84 \mathrm{~W}$ to $20.76 \mathrm{~W}$. The greatest inaccuracies derive from the Duffie et al. and 
the Averbukh et al. models. Differences, varying between $46.61 \mathrm{~W}$ and $97.01 \mathrm{~W}$, were calculated. Townsend $\mathrm{n} .2$ model yields the smallest $\mathrm{MD}(P)$ s for the Sanyo PV module, which are in the range from $19.19 \mathrm{~W}$ to $24.26 \mathrm{~W}$. The greatest values are obtained with the Averbukh et al., the Saloux et al. and the Mahmoud et al. n.1 models. Such differences vary from $49.94 \mathrm{~W}$ to $92.72 \mathrm{~W}$.

\section{Rating of the Usability and Accuracy of the Simplified One-Diode Models}

In order to rate the usability and accuracy of the analysed models, the same approach used in [1] was adopted. The rating criterion is based on a three-level rating scale that takes into consideration the following features:

- $\quad$ the ease of finding the performance data used by the analytical procedure;

- the simplicity of the mathematical tools needed to perform calculations;

- the accuracy achieved in calculating the current and power of the analysed PV modules.

The ease of finding the input data is assumed:

- high, when only tabular data are required (short circuit current, open circuit voltage, MPP current and voltage);

- $\quad$ medium, when the data have to be extracted by reading the $I-V$ characteristics (open circuit voltage at conditions different from the SRC);

- $\quad l o w$, when the derivative of the $I-V$ curves are required.

The simplicity of the used mathematical tools is considered:

- high, if only simple calculations are necessary;

- medium, if an iterative procedure, which not necessarily requires dedicated computational software, is used;

- low, when the analytical procedure requires the use of numerical solvers or complex mathematical methods usually implemented in dedicated computational software.

Table 15 lists the average ratios of $\operatorname{MAD}(I)$ to the rated current at the MPP, and of $\operatorname{MAD}(P)$ to the rated maximum power, extracted from Tables 5 and 6.

Table 15. Average ratios of $\operatorname{MAD}(I)$ to the rated current at the MPP andof $\operatorname{MAD}(P)$ to the rated maximum power.

\begin{tabular}{|c|c|c|c|c|c|}
\hline \multirow{3}{*}{ Model } & \multicolumn{2}{|c|}{ Average MAD(I)/I $m_{m p, r e f}(\%)$} & \multicolumn{2}{|c|}{ Average $\mathrm{MAD}(P) / V_{m p, r e f} I_{m p, r e f}(\%)$} & \multirow{3}{*}{$\begin{array}{l}\text { Global } \\
\text { Accuracy }\end{array}$} \\
\hline & Kyocera & Sanyo & Kyocera & Sanyo & \\
\hline & KD245GH-4FB2 & HIT-240 HDE4 & KD245GH-4FB2 & HIT-240 HDE4 & \\
\hline Townsend n.1 & 2.56 & 3.00 & 2.54 & 3.10 & 2.80 \\
\hline Townsend n.2 & 2.24 & 2.44 & 2.11 & 2.56 & 2.34 \\
\hline Duffie et al. & 3.86 & 2.81 & 3.91 & 2.91 & 3.37 \\
\hline Xiao et al. & 3.66 & 5.20 & 3.88 & 5.66 & 4.60 \\
\hline Ulapane et al. & 1.83 & 3.07 & 1.79 & 3.18 & 2.47 \\
\hline Saloux et al. & 2.81 & 3.25 & 2.81 & 3.37 & 3.06 \\
\hline Mahmoud et al. n.1 & 4.74 & 4.57 & 4.67 & 4.75 & 4.68 \\
\hline Averbukh et al. & 4.27 & 4.96 & 4.21 & 5.19 & $\overline{4.66}$ \\
\hline Mahmoud et al. n.2 & 2.03 & 3.11 & 2.01 & 3.23 & 2.60 \\
\hline
\end{tabular}

It can be observed that the global accuracy listed in Table 15, which is calculated averaging the accuracies evaluated for the Kyocera and Sanyo PV panels, ranges from $2.34 \%$ to $4.68 \%$. Such range of variation was divided in three equal intervals, which were used to qualitatively describe the accuracy of the analysed models: 
- $\quad$ high, for values of the mean difference in the subrange $2.34 \%$ to $3.12 \%$;

- medium, for values of the mean difference in the subrange $3.12 \%$ to $3.90 \%$;

- low, for values of the mean difference in the subrange $3.90 \%$ to $4.68 \%$.

Table 16 lists the rating of the ease of finding data, simplicity of mathematical tools, and accuracy in calculating the current and power, based on the three-level rating scale previously described.

Table 16. Usability and accuracy ratings of the analysed one-diode models.

\begin{tabular}{cccc}
\hline MODEL & Ease of Data Finding & Mathematical Simplicity & Current and Power Accuracy \\
\hline Townsend n.1 & High & Low & High \\
Townsend n. & High & High & High \\
Duffie et al. & Medium & High & Medium \\
Xiao et al. & High & Medium & Low \\
Ulapane et al. & High & Medium & High \\
Saloux et al. & High & High & High \\
Mahmoud et al. n.1 & High & Low & Low \\
Averbukh et al. & High & Low & Low \\
Mahmoud et al. n.2 & High & High & High \\
\hline
\end{tabular}

Excepting the Duffie et al. model, only data that are easy to be found are required by the models. Some models, such as Xiao et al., Mahmoud et al. n.1 and Averbukh et al. reach a small accuracy and present some mathematical difficulties. Other models such as the Townsend n.1 model and the Ulapane et al. model are more accurate. The Townsend n.2 model, Saloux et al. model and Mahmoud et al. n.2 model, which have high ratings for both the usability and accuracy, may be considered the best option among the simplified one-diode models.

In order to assess the suitability of using simplified one-diode models, it would be interesting to make a comparison with the performances of the best known one-diode models, when they are used to calculate the $I-V$ characteristics of the same PV panels. Table 17 lists the usability and accuracy ratings of the one-diode models described in [1] along with the ones of the simplified one-diode models analysed in the present paper. To make a consistent comparison, the accuracy was rated considering the smallest and the greatest mean differences calculated for both the one-diode models and the simplified one-diode models. According to such extreme values, the following accuracy subranges were defined:

- $\quad$ high, for values of the mean difference in the subrange $0.53 \%$ to $1.91 \%$;

- medium, for values of the mean difference in the subrange $1.91 \%$ to $3.30 \%$;

- low, for values of the mean difference in the subrange $3.30 \%$ to $4.68 \%$.

The choice of the best model requires a wise compromise between usability and accuracy because no model achieves the highest ratings for all the considered features. In selecting a model one may prefer the usability to the accuracy, the accuracy to the usability, or try to find an acceptable balance between such features. As it was predictable, the models that reach a great accuracy require data more difficult to be found; adversely, the models based on data that can be easily read on the issued datasheets are generally less accurate. The best ratings are obtained by the Orioli et al. model, the Townsend n.2 model, the Saloux et al. model and the Mahmoud et al. n.2 model. The Orioli et al. model reaches a high precision although it presents some mathematical difficulties; the Townsend n. 2 model, the Saloux et al. model and the Mahmoud et al. $n .2$ model are less precise but the model parameters can be easily calculated. 
Table 17. Usability and accuracy ratings of the analysed one-diode based models.

\begin{tabular}{|c|c|c|c|c|}
\hline \multicolumn{2}{|c|}{ Model } & $\begin{array}{l}\text { Ease of Data } \\
\text { Finding }\end{array}$ & $\begin{array}{l}\text { Mathematical } \\
\text { Simplicity }\end{array}$ & $\begin{array}{c}\text { Current and Power } \\
\text { Accuracy }\end{array}$ \\
\hline \multirow{9}{*}{ One-diode } & Hadj Arab et al. & Low & High & Medium \\
\hline & De Soto et al. & Medium & Low & Medium \\
\hline & Sera et al. & Low & Medium & Medium \\
\hline & Villalva et al. & High & Medium & Medium \\
\hline & Lo Brano et al. & Low & Medium & High \\
\hline & Seddaoui et al. & Low & High & Medium \\
\hline & Siddique et al. & High & Medium & Medium \\
\hline & Yetayew et al. & Medium & Low & Medium \\
\hline & Orioli et al. & High & Medium & High \\
\hline \multirow{9}{*}{ Simplified one-diode } & Townsend n.1 & High & Low & Medium \\
\hline & Townsend n.2 & High & High & Medium \\
\hline & Duffie et al. & Medium & High & Low \\
\hline & Xiao et al. & High & Medium & Low \\
\hline & Ulapane et al. & High & Medium & Medium \\
\hline & Saloux et al. & High & High & Medium \\
\hline & Mahmoud et al. n.1 & High & Low & Low \\
\hline & Averbukh et al. & High & Low & Low \\
\hline & Mahmoud et al. n.2 & High & High & Medium \\
\hline
\end{tabular}

\section{Conclusions}

The analytical procedures to calculate the parameters of the models based on the simplified one-diode equivalent circuit were described, along with the simplifying hypotheses adopted. The models were used to calculate the $I-V$ curves at constant cell temperature and solar irradiance using the data extracted from the manufacturers' datasheets for two different types of PV modules. The calculated $I-V$ curves were compared with the issued $I-V$ characteristics in order to test the accuracy achievable by means of the analysed models. The model accuracies were quantified through the maximum difference and the mean absolute difference between the calculated values of current and the numerous values of current extracted from the issued $I-V$ characteristics; the maximum difference and the mean absolute difference for the generated power were also evaluated.

Depending on the used model and the considered $I-V$ curve, the most effective simplified one-diode equivalent circuits yielded for the poly-crystalline Kyocera KD245GH-4FB2 PV panel values of the current difference that averagely vary between $0.97 \%$ and $2.71 \%$ of the current at the MPP. The values of the power difference averagely ranged $0.97 \%$ to $2.49 \%$ of the rated maximum power. Smaller accuracies were generally observed for the Sanyo HIT-240 HDE4 PV module. The current differences averagely range $1.05 \%$ to $3.18 \%$ of the current at the MPP. The power accuracies averagely vary between $0.93 \%$ and $3.05 \%$ of the rated maximum power. The accuracies of the less effective models averagely reached $15.03 \%$ of the current at the MMP and $14.26 \%$ of the rated maximum power for the Kyocera PV panel, whereas average differences of $13.13 \%$ of the current at the MMP and of $13.25 \%$ of the rated maximum power were observed for the Sanyo PV module.

No model achieves the highest ratings for all the considered features. On the basis of the obtained results, the Townsend $n .2$ model and the Ulapane et al. model may be on average considered the most effective among the simplified one diode analysed models. If the model selection is extended to all the one-diode based models, the best ratings are given to the Orioli et al. model, the Townsend n.2 model, the Saloux et al. model and the Mahmoud et al. n.2 model. Actually it is not a trivial matter to identify the most accurate model because, depending on the type of PV panel and the particular $I-V$ characteristic considered, the greatest accuracies are never obtained by means of the same model. Moreover, the aim of this paper is not to select the most effective model, but provide information useful to choose the analytical procedure that represents the best compromise between expected accuracy and mathematical complexity. Such a choice, which has to be wisely made aiming to the specific purpose, may be effectively supported by the results of the presented comparison. 
Author Contributions: Aldo Orioli and Alessandra Di Gangi conceived and performed the criterion; Vincenzo Franzitta and Aldo Orioli carried out the analysis between the characteristics of the PV modules and the calculated current-voltage curves; Aldo Orioli and Alessandra Di Gangi wrote the paper.

Conflicts of Interest: The authors declare no conflicts of interest.

\section{Appendix A}

In this appendix the equations used by the various simplified one-diode models to describe the physical properties of PV panels are listed along with the analytical procedures adopted to get the explicit or implicit expressions necessary to calculate the equivalent model parameters.

\section{Appendix A.1. Townsend n.1 Model}

Townsend observed that, for the four-parameter equivalent circuit, it was not necessary to assign arbitrary values to any of the parameters because they could be univocally determined from the information usually provided by manufacturers at the SRC:

(1) short circuit point $\left[I=I_{s c, \text { ref }} ; V=0\right]$;

(2) open circuit point $\left[I=0 ; V=V_{o c, \text { ref }}\right]$;

(3) $\operatorname{MPP}\left[I=I_{m p, r e f} ; V=V_{m p, r e f}\right]$;

(4) derivative of power at the MPP $\left[\partial P / \partial V=0\right.$ at $\left.I=I_{m p, r e f} ; V=V_{m p, r e f}\right]$.

Using the previous information, the following equations can be written:

- $\quad I=I_{s c, r e f}$ and $V=0$ :

$$
I_{s c, \text { ref }}=I_{L, r e f}-I_{0, r e f}\left(e^{\frac{I_{s c, r e f} R_{s}}{n T_{r e f}}}-1\right)
$$

- $\quad I=0$ and $V=V_{o c, r e f}$ :

$$
0=I_{L, \text { ref }}-I_{0, \text { ref }}\left(e^{\frac{V_{o c, \text { ref }}}{n T_{\text {ref }}}}-1\right)
$$

- $\quad I=I_{m p, r e f}$ and $V=V_{m p, r e f}$ :

$$
I_{m p, r e f}=I_{L, r e f}-I_{0, r e f}\left(e^{\frac{V_{m p, r e f}+I_{m p, r e} R_{s}}{n T_{r e f}}}-1\right)
$$

- $\partial P / \partial V=0$ at $I=I_{m p, r e f}$ and $V=V_{m p, r e f}$ :

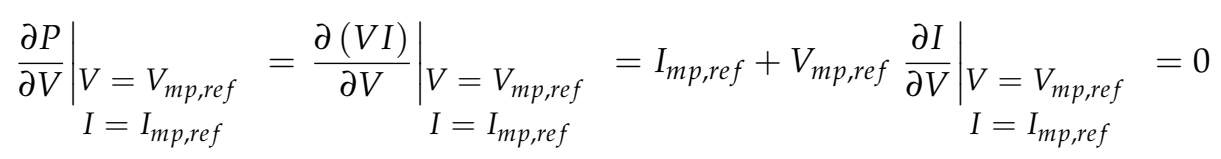

Because the partial derivative of the current is:

$$
\frac{\partial I}{\partial V}=-\frac{\frac{I_{0, r e f}}{n T_{r e f}} e^{\frac{V+I R_{s}}{n T_{r e f}}}}{1+R_{s} \frac{I_{0, r e f}}{n T_{r e f}} e^{\frac{V+I R_{s}}{n T_{r e f}}}}
$$


Equation (A4) is rewritten as:

$$
I_{L, r e f}+I_{0, r e f}-I_{0, \text { ref }} e^{\frac{V_{m p, r e f}+I_{m p, r e f} R_{s}}{n T_{r e f}}}\left(1+\frac{\frac{1}{n T_{r e f}}}{1+R_{S} \frac{I_{0, r e f}}{n T_{\text {ref }}} e^{\frac{V_{m p, r e f}+I_{m p, r e f} R_{s}}{n T_{\text {ref }}}}}\right)=0
$$

To calculate the model parameters, the system of Equations (A1)-(A3) and (A6) was solved by Townsend by means of the Newton-Raphson method, which requires the direct calculation of the derivative of equations and the definition of initial values of parameters $I_{L, \text { ref }}, I_{0, \text { ref }}, n$ and $R_{s}$ within approximately an order of magnitude of the correct values, which is not an easy task. Unfortunately, the Newton-Raphson method, while rigorous, is fairly unstable and requires many computational steps to calculate the system parameters. In order to consider the effects of solar irradiance $G$ and cell temperature $T$, Townsend proposed to use the following equations:

$$
\begin{gathered}
I_{L}(G, T)=\left[I_{s c, r e f}+\mu_{I, s c}\left(T-T_{r e f}\right)\right] \frac{G}{G_{r e f}} \\
I_{0}(T)=I_{0, r e f}\left(\frac{T}{T_{r e f}}\right)^{3} e^{\frac{N_{c s} E_{G}}{n}\left(\frac{1}{T_{r e f}}-\frac{1}{T}\right)}
\end{gathered}
$$

in which $\varepsilon_{G}$, which is set $1.12 \mathrm{eV}$ for $\mathrm{Si}$ and $1.35 \mathrm{eV}$ for GaAs, is the bandgap energy of the material.

Appendix A.2. Townsend n.2 Model

The same information used by the Townsend n.1 model is considered. Assuming the following hypotheses:

$$
e^{\frac{I_{s c, \text { ref }} R_{S}}{n T_{\text {ref }}}} \approx 1 \quad e^{\frac{V_{o c, r e f}}{n T_{r e f}}}>>1 \quad e^{\frac{V_{m p, r e f}}{n T_{r e f}}}>>1
$$

Equations (A1)-(A3) can be rewritten as:

$$
\begin{gathered}
I_{s c, r e f}=I_{L, r e f} \\
0=I_{L, r e f}-I_{0, r e f} e^{\frac{V_{o c, r e f}}{n T_{r e f}}} \\
I_{m p, r e f}=I_{L, r e f}-I_{0} e^{\frac{V_{m p, r e f}+I_{m p, r e f} R_{s}}{n T_{r e f}}}=I_{s c, r e f}\left(1-e^{\frac{V_{m p, r e f}+I_{m p, r e f} R_{s}-V_{o c, r e f}}{n T_{r e f}}}\right)
\end{gathered}
$$

From Equations (A11) and (A12) the expressions of $I_{0, \text { ref }}$ and $R_{s}$ are obtained:

$$
\begin{gathered}
I_{0, \text { ref }}=I_{s c, \text { ref }} e^{-\frac{V_{o c, \text { ref }}}{n T_{\text {ref }}}} \\
R_{s}=\frac{n T_{\text {ref }} \ln \left(1-\frac{I_{m p, r e f}}{I_{s c, \text { ref }}}\right)+V_{o c, r e f}-V_{m p, r e f}}{I_{m p, r e f}}
\end{gathered}
$$

Because of Equation (A13), it is:

$$
I=I_{L, r e f}-I_{0, r e f}\left(e^{\frac{V+I R_{S}}{n T_{\text {ref }}}}-1\right)=I_{s c, \text { ref }}\left(1-e^{\frac{V+I R_{S}-V_{\text {oc ref }}}{n T_{\text {ref }}}}+e^{-\frac{V_{o c, \text { ref }}}{n T_{\text {ref }}}}\right)
$$


Equations (A5) and (A4) can be rewritten as:

$$
\begin{gathered}
\frac{\partial I}{\partial V}=-\frac{\frac{I_{s c, r e f}}{n T_{r e f}} e^{\frac{V+I R_{s}-V_{o c, r e f}}{n T_{r e f}}}}{1+R_{s} \frac{I_{s c, r e f}}{n T_{r e f}} e^{\frac{V+I R_{s}-V_{o c, r e f}}{n T_{r e f}}}} \\
I_{s c, r e f}\left(1-e^{\frac{V_{m p, r e f}+I_{m p, r e f} R_{s}-V_{o c, r e f}}{n T_{r e f}}}\right)-\frac{\frac{V_{m p, r e f} I_{c, r e f}}{n T_{r e f}}}{1+R_{s} \frac{I_{s c, r e f}}{n T_{r e f}} e^{\frac{V_{m p, r e f}+I_{m p, r e f} R_{s}-V_{o c, r e f}}{n T_{r e f}}}}=0
\end{gathered}
$$

Moreover, considering that from Equations (A12) and (A14) it is:

$$
\begin{aligned}
& I_{s c, r e f}\left(1-e^{\frac{V_{m p, r e f}+I_{m p, r e f} R_{s}-V_{o c, r e f}}{n T_{r e f}}}\right)=I_{s c, r e f}-I_{m p, r e f} \\
& \frac{I_{m p, r e f} R_{s}}{n T_{r e f}}=\ln \left(1-\frac{I_{m p, r e f}}{I_{s c, r e f}}\right)+\frac{V_{o c, r e f}-V_{m p, r e f}}{n T_{r e f}}
\end{aligned}
$$

Equation (A17) can be solved in order to obtain the following expression:

$$
n=\frac{2 V_{m p, r e f}-V_{o c, r e f}}{T_{r e f}\left[\frac{I_{m p, r e f}}{I_{s c, r e f}-I_{m p, r e f}}+\ln \left(1-\frac{I_{m p, r e f}}{I_{s c, r e f}}\right)\right]}
$$

The values of $I_{L, r e f}, n, I_{0, r e f}$ and $R_{S}$ can be calculated by means of the explicit expressions (A10), (A20), (A13) and (A14). Townsend again suggested using of Equations (A7) and (A8) to describe the electrical behaviour of the analysed PV device far from the SRC.

Appendix A.3. Townsend n.3 Model

The following information is used:

(1) short circuit point $\left[I=I_{s c, r e f} ; V=0\right]$;

(2) open circuit point $\left[I=0 ; V=V_{o c, \text { ref }}\right]$;

(3) $\mathrm{MPP}\left[I=I_{m p, r e f} ; V=V_{m p, r e f}\right]$;

(4) derivative of the open circuit voltage $\left[\partial V_{o c} / \partial T=\mu_{V, o c}\right.$ at the SRC $]$.

The same hypotheses of Equation (A9) are considered. Equations (A10) and (A13) are used to calculate $I_{L, r e f}$ and $I_{0, \text { ref }}$, whereas diode quality factor $n$ is extracted from Equation (A12):

$$
n=\frac{V_{m p, r e f}+I_{m p, r e f} R_{s}-V_{o c, r e f}}{T_{r e f} \ln \left(1-\frac{I_{m p, r e f}}{I_{s c, r e f}}\right)}
$$

Considering the fourth piece of information, an equation can be written by differentiating the expression of the open voltage obtained from Equations (A10) and (A11):

$$
\begin{aligned}
\mu_{V, o c}=\left.\frac{\partial V_{o c}}{\partial T}\right|_{T} & =T_{r e f}=\frac{\partial}{\partial T}\left[n T \ln \left(\frac{I_{s c}}{I_{0}}\right)\right]_{T}=T_{r e f} \\
G & =G_{r e f} \\
G & =G_{r e f}
\end{aligned}
$$


If Equations (A7) and (A8) are used to describe the dependence of $I_{s c}$ and $I_{0}$ on the cell temperature, the following expression is obtained:

$$
\frac{\partial V_{o c}}{\partial T}=n\left[\ln \left(\frac{I_{s c}}{I_{0}}\right)+\frac{\mu_{I, s c} T}{I_{s c, r e f}+\mu_{I, s c}\left(T-T_{r e f}\right)}-\left(3+\frac{N_{c s} \varepsilon_{G}}{n T}\right)\right]
$$

that, at the SRC, becomes:

$$
\mu_{V, o c}=\left.\frac{\partial V_{o c}}{\partial T}\right|_{\substack{T \\ G=T_{r e f} \\ G=G_{r e f}}}=n\left[\ln \left(\frac{I_{s c, r e f}}{I_{0, r e f}}\right)+\frac{\mu_{I, s c} T_{r e f}}{I_{s c, r e f}}-\left(3+\frac{N_{c s} \varepsilon_{G}}{n T_{r e f}}\right)\right]
$$

It is evident that Equation (A24) can be calculated only if $n$ and $I_{0, \text { ref }}$ are known. Moreover, diode reverse saturation current $I_{0, \text { ref }}$ in Equation (A13) depends on $n$ and, in turn, the diode quality factor can be evaluated with Equation (A21) only if $R_{s}$ is known. To calculate the model parameters with the above implicit equations, Townsend proposed an iterative procedure based on the following steps:

(1) $I_{L, r e f}$ is calculated by Equation (A10);

(2) an initial value of $R_{S}$ is assumed;

(3) $n$ is calculated by Equation (A21);

(4) $I_{0, \text { ref }}$ is calculated by Equation (A13);

(5) $\mu_{V, o c}$ is compared with the value calculated by Equation (A24);

(6) the analytical procedure is concluded if the comparison is satisfied within a fixed accuracy; otherwise, a new value of $R_{s}$ is assumed and the iterative procedure is repeated.

Townsend suggested using Equations (A7) and (A8) to describe the electrical behaviour of the analysed PV module far from the SRC. The Townsend n.3 model was also used by Chenni et al. [73] who partially issued the MS thesis of Eckstein [74].

\section{Appendix A.4. Duffie and Beckman Model}

The same information used by the Townsend n.3 model is used. Because the hypotheses of Equation (A9) are adopted, it is:

$$
\begin{gathered}
I_{L, r e f}=I_{s c, r e f} \\
I_{0, r e f}=I_{s c, r e f} e^{-\frac{V_{o c, r e f}}{n T_{r e f}}}
\end{gathered}
$$

Equation (A14) is used to calculate $R_{s}$ :

$$
R_{s}=\frac{n T_{r e f} \ln \left(1-\frac{I_{m p, r e f}}{I_{s c, r e f}}\right)-V_{m p, r e f}-V_{o c, r e f}}{I_{m p . r e f}}
$$

If the following relation:

$$
\ln \left(\frac{I_{s c, r e f}}{I_{0, r e f}}\right)=\frac{V_{o c, r e f}}{n T_{r e f}}
$$

which is derived from Equation (A26), is used in Equation (A24), it is possible to rewrite $\mu_{V, o c}$ in the form:

$$
\mu_{V, o c}=\left.\frac{\partial V_{o c}}{\partial T}\right|_{\substack{T \\ G=T_{r e f} \\ G=G_{r e f}}}=\frac{V_{o c, r e f}}{T_{r e f}}+\frac{n \mu_{I, s c} T_{r e f}}{I_{s c, r e f}}-\left(3 n+\frac{N_{c s} \varepsilon_{G}}{T_{r e f}}\right)
$$


Parameter $n$ is extracted from Equation (A29):

$$
n=\frac{\mu_{V, o c} T_{r e f}-V_{o c, r e f}+N_{c s} \varepsilon_{G}}{T_{r e f}\left(\frac{\mu_{I, s c} T_{r e f}}{I_{s c, r e f}}-3\right)}
$$

Parameters $I_{L, \text { ref }}, I_{0, \text { ref }}, R_{S}$ and $n$ can be calculated with Equations (A25)-(A27) and (A30). The effects of solar irradiance and cell temperature are evaluated using Equations (A7) and (A8). This method was adopted by Kou et al. [75] to estimate the long-term performance of direct-coupled PV pumping system. The model was also experimentally verified by Celik et al. [76].

\section{Appendix A.5. Xiao, Dunford and Capel Model}

The model uses the following information:

(1) short circuit point $\left[I=I_{s c, r e f} ; V=0\right]$;

(2) open circuit point $\left[I=0 ; V=V_{o c, r e f}\right]$;

(3) $\mathrm{MPP}\left[I=I_{m p, r e f} ; V=V_{m p, r e f}\right]$;

(4) derivative of power at the MPP $\left[\partial P / \partial V=0\right.$ at $\left.I=I_{m p, r e f} ; V=V_{m p, r e f}\right]$.

Assuming the hypothesis:

$$
e^{\frac{I_{s c, r e f} R_{s}}{n T_{r e f}}} \approx 1
$$

from Equations (A1)-(A3) the following expressions of $I_{L, \text { ref }}, I_{0, \text { ref }}$ and $R_{S}$ can be extracted:

$$
\begin{gathered}
I_{L, r e f}=I_{s c, r e f} \\
I_{0, r e f}=\frac{I_{s c, r e f}}{e^{\frac{V_{c c}, r e f}{n T_{r e f}}}-1} \\
R_{S}=\frac{n T_{r e f} \ln \left[\left(1-\frac{I_{m p, r e f}}{I_{s c, r e f}}\right) e^{\frac{V_{o c}}{n T}}+\frac{I_{m p, r e f}}{I_{s c, r e f}}\right]-V_{m p, r e f}}{I_{m p, r e f}}
\end{gathered}
$$

From Equation (A4), which describes the condition related to the derivative of the analytical power-voltage curve, the following equation can be obtained:

$$
\begin{aligned}
& \left.\frac{\partial I}{\partial V}\right|_{V=V_{m p, r e f}}+\frac{I_{m p, r e f}}{V_{m p, r e f}}=0 \\
& I=I_{m p, r e f}
\end{aligned}
$$

If Equation (A5) is used, Equation (A35) can be rewritten as:

$$
\frac{I_{m p, r e f}}{V_{m p, r e f}}-\frac{\frac{I_{0, r e f}}{n T_{r e f}} e^{\frac{V_{m p, r e f}+I_{m p, r e f} R_{s}}{n T_{r e f}}}}{1+R_{s} \frac{I_{0, r e f}}{n T_{r e f}} e^{\frac{V_{m p, r e f}+I_{m p, r e f} R_{s}}{n T_{r e f}}}}=0
$$

Parameters $I_{L, r e f}, I_{0, r e f}, n$ and $R_{s}$ may be calculated with Equations (A32)-(A34) if parameter $n$, was known; such a parameter is also present in Equation (A36), which describes the condition related to the derivative of the analytical power-voltage curve. Because of the presence of implicit equations, the model parameters are calculated with the following iterative procedure:

(1) $I_{L, \text { ref }}$ is calculated by Equation (A32);

(2) an initial value of $n$ is assumed; 
(3) $I_{0, \text { ref }}$ is calculated by Equation (A33);

(4) $R_{s}$ is calculated by Equation (A34);

(5) Equation (A36) is calculated;

(6) the analytical procedure is concluded if Equation (A36) is verified within a fixed accuracy; otherwise, a new value of $n$ is assumed and the iterative procedure is repeated.

In order to take account of the effects of solar irradiance and cell temperature different from the SRC, photocurrent $I_{L}$ is calculated with Equation (A7), whereas reverse saturation current $I_{0}$ is evaluated by means of the following equation, which is derived from Equation (A33):

$$
I_{0}(G, T)=\frac{\left[I_{s c, r e f}+\mu_{I, s c}\left(T-T_{r e f}\right)\right] \frac{G}{G_{r e f}}}{e^{\frac{V_{o c, r e f}+\mu_{V, o c}\left(T-T_{r e f}\right)}{n T}}-1}
$$

where thermal coefficient $\mu_{I, s c}$ and $\mu_{V, o c}$ are used.

Appendix A.6. Ulapane, Dhanapala, Wickramasinghe, Abeyratne, Rathnayake and Binduhewa Model

Because the same information an hypothesis used by the Xiao et al. model are considered, currents $I_{L, \text { ref }}$ and $I_{0, \text { ref }}$ can be calculated with Equations (A32) and (A33). From the condition describing the MPP, the following expressions are obtained:

$$
\begin{gathered}
R_{s}=\frac{n T_{r e f}}{I_{m p, r e f}} \ln \left(\frac{I_{L, \text { ref }}-I_{m p, r e f}+I_{0, \text { ref }}}{I_{0, \text { ref }}}\right)-\frac{V_{m p, r e f}}{I_{m p, r e f}} \\
I_{0, \text { ref }} e^{\frac{V_{m p, r e f}+I_{m p, r e f} R_{s}}{n T_{r e f}}}=I_{L, \text { ref }}-I_{m p, \text { ref }}+I_{0, \text { ref }}
\end{gathered}
$$

Equation (A36), which refers to the derivative of the power in the MPP, can be rewritten in the following form:

$$
\frac{n T_{r e f} I_{m p, r e f}+\left(I_{m p, r e f} R_{s}-V_{m p, r e f}\right) I_{0, r e f} e^{\frac{V_{m p, r e f}+I_{m p, r e f} R_{s}}{n T_{r e f}}}}{V_{m p, r e f}\left(n T_{r e f}+R_{s} I_{0, r e f} e^{\frac{V_{m p, r e f}+I_{m p, r e f} R_{s}}{n T_{r e f}}}\right)}=0
$$

If Equations (A38) and (A39) are used in the above equation, the following expression, which is equivalent to Equation (A40), is obtained:

$$
n T_{r e f} I_{m p, r e f}+\left(I_{L, r e f}-I_{m p, r e f}+I_{0, r e f}\right)\left[n T_{r e f} \ln \left(\frac{I_{L, r e f}-I_{m p, r e f}+I_{0, r e f}}{I_{0, r e f}}\right)-2 V_{m p, r e f}\right]=0
$$

The model parameters are calculated with the procedure summarized in the following steps:

(1) $I_{L, \text { ref }}$ is calculated by Equation (A32);

(2) the expression of $I_{0, r e f}$ from Equation (A33) is substituted in Equation (A41);

(3) $n$ is calculated by solving Equation (A40) with the Newton-Raphson method;

(4) $I_{0, \text { ref }}$ is calculated by Equation (A33);

(5) $R_{S}$ is calculated by Equation (A38).

For conditions different from the SRC, photocurrent $I_{L}(G, T)$ is calculated with Equation (A7), whereas the following relation is adopted for the reverse saturation current:

$$
I_{0}(G, T)=\frac{I_{L}(G, T)}{e^{\frac{V_{o c}(G, T)}{n T}}-1}
$$


For the open circuit voltage, the following expression:

$$
V_{o c}(G, T)=V_{o c, r e f}+\mu_{V, o c}\left(T-T_{r e f}\right)+n T \ln \left(\frac{G}{G_{r e f}}\right)
$$

proposed by Chenlo et al. [77], is used.

Appendix A.7. Saloux, Teyssedou and Sorin Model

The model uses the following information:

(1) short circuit point $\left[I=I_{s c, \text { ref }} ; V=0\right]$;

(2) open circuit point $\left[I=0 ; V=V_{o c, \text { ref }}\right]$;

(3) $\operatorname{MPP}\left[I=I_{m p, r e f} ; V=V_{m p}\right.$,ref $]$.

that permit to write the following equations obtained by Equation (6):

$$
\begin{gathered}
I_{s c, \text { ref }}=I_{L, \text { ref }} \\
0=I_{L, \text { ref }}-I_{0, \text { ref }}\left(e^{\frac{V_{o c, \text { ref }}}{n T_{\text {ref }}}}-1\right) \\
I_{m p, \text { ref }}=I_{L, \text { ref }}-I_{0, \text { ref }}\left(e^{\frac{V_{m p, r e f}}{n T_{\text {ref }}}}-1\right)
\end{gathered}
$$

If it is assumed:

$$
e^{\frac{V_{o c, r e f}}{n T_{\text {ref }}}}>>1 \quad e^{\frac{V_{m p, r e f}}{n T_{\text {ref }}}}>>1
$$

it is possible to extract $I_{0, \text { ref }}$ from Equation (A45):

$$
I_{0, r e f}=I_{s c, r e f} e^{-\frac{V_{o c, r e f}}{n T_{r e f}}}
$$

Equation (A48) can be substituted in Equation (A46) in order to write the following expression:

$$
I_{m p, r e f}=I_{L, r e f}-I_{L, r e f} e^{\frac{V_{m p, r e f}-V_{o c, r e f}}{n T_{r e f}}}
$$

from which parameter $n$ is extracted:

$$
n=\frac{V_{m p, r e f}-V_{o c, r e f}}{T_{r e f} \ln \left(1-\frac{I_{m p, r e f}}{I_{L, \text { ref }}}\right)}
$$

the parameters of the model can be calculated with the following sequence of steps:

(1) $I_{L, \text { ref }}$ is calculated by Equation (A44);

(2) $n$ is calculated by Equation (A50);

(3) $I_{0, r e f}$ is calculated by Equation (A48).

To take account of the effects of values of the solar irradiance and cell temperature different from the SRC, photocurrent $I_{L}$ and reverse saturation current $I_{0}$ are calculated with Equations (A7), (A42) and (A43). 
Appendix A.8. Mahmoud, Xiao and Zeineldin n.1 Model

The same information used by the Saloux et al. model is considered. Due to the use of Equation (6), currents $I_{L, \text { ref }}$ and $I_{0, \text { ref }}$ can be calculated with Equations (A32) and (A33). Equation (A33) is substituted in Equation (A46) to calculate parameter $n$ :

$$
I_{m p, r e f}=I_{s c, \text { ref }}-\frac{I_{s c, \text { ref }}}{e^{\frac{V_{o c, r e f}}{n T_{\text {ref }}}}-1}\left(e^{\frac{V_{m p, r e f}}{n T_{r e f}}}-1\right)
$$

The model parameters are calculated with the following procedure:

(1) $I_{L, \text { ref }}$ is calculated by Equation (A32);

(2) $n$ is calculated by solving Equation (A51) by means of numerical methods;

(3) $I_{0, r e f}$ is calculated by Equation (A33).

In order to use the model for values of the solar irradiance and cell temperature different from the SRC, it is assumed that:

$$
\mu_{V, o c}\left(T-T_{r e f}\right)=V_{o c}(G, T)-V_{o c}\left(G, T_{r e f}\right)
$$

Because in the open circuit point it is:

$$
0=I_{L}(G, T)-I_{0}(G, T)\left[e^{\frac{V_{o c}(G, T)}{n T}}-1\right]
$$

the following forms can be substituted in Equation (A52):

$$
\begin{gathered}
V_{o c}(G, T)=n T \ln \left[\frac{I_{L}(G, T)}{I_{0}(G, T)}+1\right] \\
V_{o c}\left(G, T_{r e f}\right)=n T \ln \left[\frac{I_{L}\left(G, T_{r e f}\right)}{I_{0, r e f}}+1\right]
\end{gathered}
$$

Due to the above substitutions, and expressing $I_{L}(G, T)$ with Equation (A7), it is possible to extract $I_{0}(G, T)$ from Equation (A52):

$$
I_{0}(G, T)=\frac{e^{-\frac{\mu_{V, o c}\left(T-T_{r e f}\right)}{n T}}\left[I_{s c, r e f}+\mu_{I, s c}\left(T-T_{r e f}\right)\right] \frac{G}{G_{r e f}}}{\left(\frac{I_{s c, r e f} G}{I_{0, r e f} G_{r e f}}+1\right)^{\frac{T_{r e f}}{T}}-e^{-\frac{\mu_{V, o c}\left(T-T_{r e f}\right)}{n T}}}
$$

Equations (A7) and (A56) are used in Equation (6) to calculate the $I-V$ characteristics for any values of $G$ and $T$.

\section{Appendix A.9. Cristaldi, Faifer, Rossi and Toscani Model}

The model uses the following information:

(1) short circuit point $\left[I=I_{s c, r e f} ; V=0\right]$;

(2) open circuit point $\left[I=0 ; V=V_{o c, r e f}\right]$;

(3) $\operatorname{MPP}\left[I=I_{m p, r e f} ; V=V_{m p, r e f}\right]$;

(4) derivative of power at the MPP $\left[\partial P / \partial I=0\right.$ at $\left.I=I_{m p, r e f} ; V=V_{m p, r e f}\right]$.

The following hypotheses are also adopted:

$$
e^{\frac{I_{s c, r e f} R_{s}}{n T_{r e f}}} \approx 1 \quad e^{\frac{V_{o c, r e f}}{n T_{r e f}}}>>1 \quad e^{-\frac{V_{o c, r e f}}{n T_{r e f}}} \approx 0
$$


From the information regarding the short circuit and open circuit points, Equations (A32) and (A13) can be obtained and used to write Equation (3) in the following form:

$$
I=I_{L, \text { ref }}-I_{0, \text { ref }}\left(e^{\frac{V+I R_{S}}{n T_{\text {ref }}}}-1\right)=I_{s c, \text { ref }}\left(1-e^{\frac{V+I R_{s}-V_{o c, r e f}}{n T_{\text {ref }}}}+e^{-\frac{V_{o c, \text { ref }}}{n T_{\text {ref }}}}\right)
$$

Considering the third hypothesis in Equation (A57), the following expression is obtained from Equation (A58):

$$
V=V_{o c, r e f}+n T_{r e f} \ln \left(1-\frac{I}{I_{s c, r e f}}\right)-I R_{s}
$$

Because of the conditions related to the MPP and the derivative of the power in the MPP, it is:

$$
\begin{gathered}
V_{m p, r e f}=V_{o c, r e f}+n T_{r e f} \ln \left(1-\frac{I_{m p, r e f}}{I_{s c, r e f}}\right)-I_{m p, r e f} R_{s} \\
\left.\frac{\partial P}{\partial I}\right|_{\substack{V=V_{m p, r e f} \\
I=I_{m p, r e f}}}=\left.\frac{\partial(V I)}{\partial I}\right|_{\substack{V=V_{m p, r e f} \\
I=I_{m p, r e f}}}=\left.I_{m p, r e f} \frac{\partial V}{\partial I}\right|_{V=V_{m p, r e f}}+I_{m p, r e f}
\end{gathered}+V_{m p, r e f}=0
$$

Because $I_{0, \text { ref }}<<I_{L, \text { ref }}$, the derivative of voltage is:

$$
\frac{\partial V}{\partial I} \mid=-\frac{n T_{r e f}}{I_{L, r e f}-I+I_{0, r e f}}-R_{s} \approx-\frac{n T_{r e f}}{I_{s c, r e f}-I}-R_{s}
$$

and Equation (A61) can be rewritten in the following form:

$$
\left.\frac{\partial(V I)}{\partial I}\right|_{\substack{V=V_{m p, r e f} \\ I=I_{m p, r e f}}}=V_{m p, r e f}-\frac{n T_{r e f} I_{m p, r e f}}{I_{s c, r e f}-I_{m p, r e f}}-I_{m p, r e f} R_{s}=0
$$

Solving Equations (A60) and (A63), the following expressions are obtained:

$$
\begin{gathered}
n=\frac{\left(2 V_{m p, r e f}-V_{o c, r e f}\right)\left(I_{s c, r e f}-I_{m p, r e f}\right)}{T_{r e f}\left[I_{m p, r e f}+\left(I_{s c, r e f}-I_{m p, r e f}\right) \ln \left(1-\frac{I_{m p, r e f}}{I_{s c, r e f}}\right)\right]} \\
R_{s}=\frac{V_{m p, r e f}}{I_{m p, r e f}}-\frac{2 V_{m p, r e f}-V_{o c, r e f}}{I_{m p, r e f}+\left(I_{s c, r e f}-I_{m p, r e f}\right) \ln \left(1-\frac{I_{m p, r e f}}{I_{s c, r e f}}\right)}
\end{gathered}
$$

The model parameters can be calculated with the following steps:

(1) $I_{L, \text { ref }}$ is calculated by Equation (A32);

(2) $n$ is calculated by Equation (A54);

(3) $I_{0, \text { ref }}$ is calculated by Equation (A13);

(4) $R_{s}$ is calculated by Equation (A65).

The effects due to values of the solar irradiance and cell temperature different from the SRC are considered by means of Equation (A7) and (A43). 
Appendix A.10. Averbukh, Lineykin and Kuperman Model

The same information used by the Cristaldi et al. model is considered. Using Equation (9), the conditions regarding the short circuit, open circuit and maximum power points correspond to the equations:

$$
\begin{gathered}
0=n T_{r e f} \ln \left(\frac{I_{L, r e f}-I_{s c, r e f}}{I_{0, r e f}}+1\right)-I_{s c, r e f} R_{s} \\
V_{o c, r e f}=n T_{r e f} \ln \left(\frac{I_{L, r e f}}{I_{0, r e f}}+1\right) \\
V_{m p, r e f}=n T_{r e f} \ln \left(\frac{I_{L, r e f}-I_{m p, r e f}}{I_{0, r e f}}+1\right)-I_{m p, r e f} R_{s}
\end{gathered}
$$

The condition for the derivative of power at the MPP is described by Equation (A61). Because the partial derivative of the voltage is:

$$
\frac{\partial V}{\partial I}=-\frac{n T_{r e f}}{I_{L, r e f}-I+I_{0, r e f}}-R_{S}
$$

Equation (A61) can be rewritten as:

$$
n T_{r e f} \ln \left(\frac{I_{L, r e f}-I_{m p, r e f}}{I_{0, r e f}}+1\right)-\left(\frac{n T_{r e f}}{I_{L, r e f}-I_{m p, r e f}+I_{0, r e f}}+2 R_{s}\right) I_{m p, r e f}=0
$$

Equations (A66), (A65), (A68) and (A70) are normalized using the following per-unit dimensionless parameters:

$$
\begin{array}{ccc}
\alpha=\frac{I_{0, \text { ref }}}{I_{L, \text { ref }}} & \beta=\frac{I_{L, r e f} R_{s}}{n T_{\text {ref }}} & v_{o c}=\frac{V_{o c}, \text { ref }}{n n T_{\text {ref }}} \\
\chi_{s c}=\frac{I_{s c, r e f}}{I_{L, \text { ref }}} & v_{m}=\frac{V_{m p, r e f}}{n T_{\text {ref }}} & \chi_{m}=\frac{I_{m, \text { ref }}}{I_{L, r e f}}
\end{array}
$$

and solved by means of a modern dedicate software. The hypothesis in Equation (5) is again assumed and, consequently, it is $I_{L, r e f}=I_{s c, \text { ref }}$. Parameters $n, I_{0, \text { ref }}$ and $R_{s}$ are extracted from the calculated values of $v_{m}, \alpha$ and $\beta$, respectively. In order to obtain the operational $I-V$ curves for arbitrary conditions of solar irradiance and cell temperature, Equation (A7) is assumed. The following equation:

$$
I_{0}(T)=I_{0, r e f} e^{\frac{N_{c s \varepsilon} \varepsilon_{G}}{n}\left(\frac{1}{T_{r e f}}-\frac{1}{T}\right)}
$$

is used to describe the reverse saturation current.

Appendix A.11. Mahmoud, Xiao and Zeineldin n.2 Model

The model is based on the same information used by Cristaldi et al. and Averbukh et al. Assuming for Equation (2) the hypotheses:

$$
e^{\frac{I_{s c, \text { re }} R_{s}}{n T_{\text {ref }}}} \approx 1 \quad \frac{I_{s c, \text { ref }} R_{s}}{R_{s h}} \approx 0
$$

the short circuit and open circuit conditions permit to write the following expressions:

$$
I_{L, r e f}=I_{s c, r e f}
$$




$$
I_{0, \text { ref }}=\frac{I_{L, \text { ref }}-V_{o c, \text { ref }} / R_{s h}}{e^{\frac{V_{o c, r e f}}{n T_{\text {ref }}}}-1}
$$

The condition on the MPP is expressed by the equation:

$$
I_{m p, r e f}=I_{L, \text { ref }}-I_{0, \text { ref }}\left(e^{\frac{V_{m p, r e f}+I_{m p, r e f} R_{s}}{n T_{\text {ref }}}}-1\right)-\frac{V_{m p, r e f}+I_{m p, r e f} R_{s}}{R_{s h}}
$$

For the five-parameter model the derivative of current at the MPP is:

$$
\left.\frac{\partial I}{\partial V}\right|_{\substack{V=V_{m p, r e f} \\ I=I_{m p, r e f}}}=-\frac{\frac{I_{0}}{n T_{\text {ref }}} e^{\frac{V_{m p, r e f}+I_{m p, r e f} R_{s}}{n T_{r e f}}}+\frac{1}{R_{s h}}}{1+R_{s}\left(\frac{I_{0}}{n T_{r e f}} e^{\frac{V_{m p, r e f}+I_{m p, r e f} R_{s}}{n T_{r e f}}}+\frac{1}{R_{s h}}\right)}
$$

If Equations (A74) and (A75) are substituted in Equations (A76) and (A4), which refers to the derivative of power at the MPP, and in Equation (A77) it is assumed that:

$$
R_{s}\left(\frac{I_{0}}{n T_{r e f}} e^{\frac{V_{m p, r e f}+I_{m p, r e f} R_{s}}{n T_{r e f}}}+\frac{1}{R_{s h}}\right)<<1
$$

the following equations can be written:

$$
\begin{gathered}
0=I_{s c, r e f}-\frac{I_{L, r e f}-V_{o c, r e f} / R_{s h}}{e^{\frac{V_{o c, r e f}}{n T_{r e f}}}-1}\left[\left(1+\frac{V_{m p, r e f}}{n T_{r e f}}\right) e^{\frac{V_{m p, r e f}+I_{m p, r e f} R_{s}}{n T_{r e f}}}-1\right]-\frac{2 V_{m p, r e f}+I_{m p, r e f} R_{s}}{R_{s h}} \\
0=\left[\frac{I_{s c, r e f} R_{s h}-V_{m p, r e f}-I_{m p, r e f}\left(R_{s}+R_{s h}\right)}{\left.I_{c c}\right)}\right] e^{\frac{V_{o c}, r e f}{n T_{r e f}}}+ \\
-e^{\frac{V_{m p, r e f}+I_{m p, r e f} R_{s, r e f}}{n T_{r e f}}}-\left[\frac{V_{o c, r e f}-V_{m p, r e f}-I_{m p, r e f}\left(R_{s, r e f}+R_{s h, r e f}\right)}{I_{s c, r e f} R_{s h}-V_{o c, r e f}}\right]
\end{gathered}
$$

The five-parameter model is transformed into a four-parameter model, in which only the series resistance, or only the shunt resistance, is present by means of the following procedure:

(1) $I_{L, \text { ref }}$ is calculated by Equation (A74);

(2) it is set $R_{s h}=\infty\left(R_{s h}=10^{7}\right)$;

(3) $\quad R_{S}$ and $n$ are calculated by simultaneously solving Equations (A79) and (A80);

(4) if a solution for $R_{s}$ and $n$, within a feasible region, is reached, then the model only contains $R_{s}$;

(5) otherwise, it is set $R_{S}=0$;

(6) $\quad R_{s h}$ and $n$ are calculated by simultaneously solving Equations (A79) and (A80);

(7) $I_{0, r e f}$ is calculated by Equation (A75).

To calculate the $I-V$ characteristics for generic values of solar irradiance and cell temperature, photocurrent $I_{L}(G, T)$ are descripted by Equation (A7). For the reverse saturation current, the following equation is used:

$$
I_{0}(G, T)=\frac{\frac{G}{G_{r e f}}\left[I_{L, r e f}+\mu_{I, s c}\left(T-T_{r e f}\right)\right] e^{\frac{\left|\mu_{V, o c}\right|\left(T-T_{r e f}\right)}{n T}}}{\left(\frac{G}{G_{r e f}} \frac{I_{s c, r e f}}{I_{0, r e f}}+1\right)^{\frac{T_{r e f}}{T}}-e^{\frac{\left|\mu_{V, o c}\right|\left(T-T_{r e f}\right)}{n T}}}
$$




\section{Nomenclature}

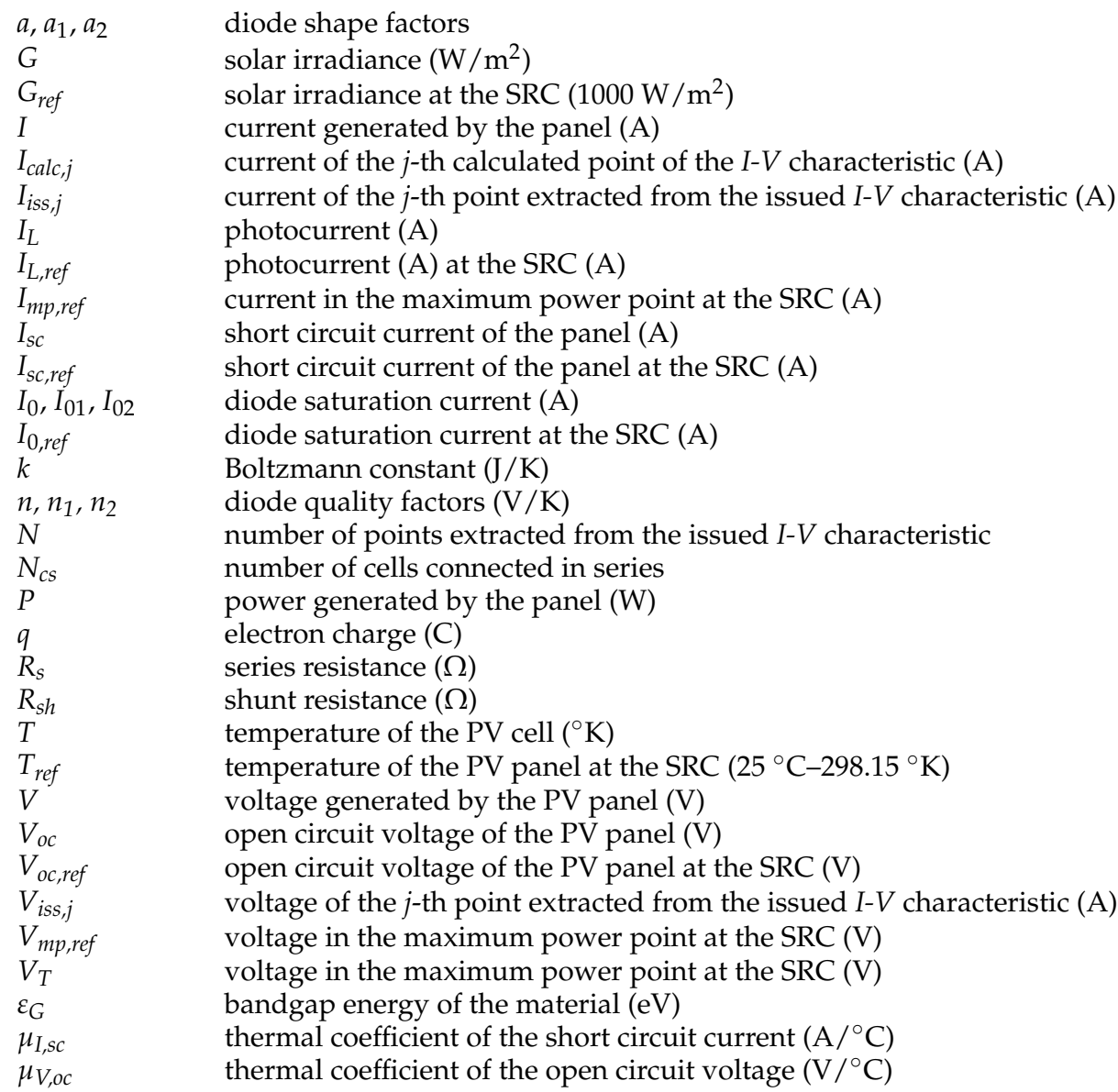

\section{References}

1. Orioli, A.; Di Gangi, A. A criterion for rating the usability and accuracy of the one-diode models for photovoltaic modules. Energies 2016, 9, 427. [CrossRef]

2. Wolf, M.; Rauscenbach, H. Series Resistance Effects on Solar Cell Measurements. Adv. Energy Convers. 1963, 3, 455-479. [CrossRef]

3. Markvart, T.; Costañer, L. Solar Cells: Materials, Manufacture and Operation; Elsevier: Oxford, UK, 2005.

4. Chan, D.S.H.; Phang, J.C.H. Analytical methods for the extraction of solar-cell single- and double-diode model parameters from $I-V$ characteristics. IEEE Trans. Electron Devices 1987, 34, 286-293. [CrossRef]

5. Enebish, N.; Agchbayar, D.; Dorjkhand, S.; Baatar, D.; Ylemj, I. Numerical analysis of solar cell current-voltage characteristics. Sol. Energy Mater. Sol. Cells 1993, 29, 201-208. [CrossRef]

6. Hovinen, A. Fitting of the solar cell IV-curve to the two diode model. Phys. Scr. 1994, T54, 175-176. [CrossRef]

7. Garrido-Alzar, C.L. Algorithm for extraction of solar cell parameters from $I-V$ curve using double exponential model. Renew. Energy 1997, 10, 125-128. [CrossRef]

8. Zhao, R.; Xu, H.; Zhao, Z.; Zhang, S. A simplified double-exponential model of potovoltaic module in matlab $^{\mathrm{TM}}$. In Proceedings of the IEEE International Conference on Energy and Environment Technology (ICEET '09), Guilin, China, 16-18 October 2009; pp. 157-160.

9. Yordanov, G.H.; Midtgård, O.M.; Saetre, T.O. Two-diode model revisited: Parameters extraction from semi-log plots of $I-V$ data. In Proceedings of the 25th European Photovoltaic Solar Energy Conference and Exhibition/5th World Conference on Photovoltaic Energy Conversion, Valencia, Spain, 6-10 September 2010; pp. 4156-4163.

10. Yordanov, G.H.; Midtgård, O.M.; Saetre, T.O. Extracting parameters from semi-log plots of polycrystalline silicon PV modules outdoor $I-V$ data: Double-exponential model revisited. In Proceedings of the 35th IEEE Photovoltaic Specialists Conference (PVSC), Honolulu, HI, USA, 20-25 June 2010; pp. 2756-2761. 
11. Ishaque, K.; Salam, Z.; Taheri, H. Simple, fast and accurate two-diode model for photovoltaic modules. Sol. Energy Mater. Sol. Cells 2011, 95, 586-594. [CrossRef]

12. Gupta, S.; Tiwari, H.; Fozdar, M.; Chandna, V. Development of a two diode model for photovoltaic modules suitable for use in simulation studies. In Proceedings of the 2012 Asia-Pacific Power and Energy Engineering Conference (APPEEC), Shanghai, China, 27-29 March 2012; pp. 1-4.

13. Maoucha, A.; Djeffal, F.; Arar, D.; Lakhdar, N.; Bendib, T.; Abdi, M.A. An accurate organic solar cell parameters extraction approach based on the illuminated $I-V$ characteristics for double diode modelling. In Proceedings of the 1st International Conference on renewable Energies and Vehicular Technology (REVET), Nabeul, Tunisia, 26-28 March 2012; pp. 74-77.

14. Hejri, M.; Mokhtari, H.; Azizian, M.R.; Ghandhari, M.; Söder, L. On the parameter extraction of a five-parameter double-diode model of photovoltaic cells and modules. IEEE J. Photovolt. 2014, 4, 915-923. [CrossRef]

15. Babu, B.C.; Gurjar, S. A novel simplified two-diode model of photovoltaic (PV) module. IEEE J. Photovolt. 2014, 4, 1156-1161. [CrossRef]

16. Ikegami, T.; Maezono, T.; Nakanishi, F.; Yamagata, Y.; Ebihara, K. Estimation of equivalent circuit parameters of PV module and its application to optimal operation of PV system. Sol. Energy Mater. Sol. Cells 2001, 67, 389-395. [CrossRef]

17. De Blas, M.A.; Torres, J.L.; Prieto, E.; Garcia, A. Selecting a suitable model for characterizing photovoltaic devices. Renew. Energy 2002, 25, 371-380. [CrossRef]

18. Hadj Arab, A.; Chenlo, F.; Benghanem, M. Loss-of-load probability of photovoltaic water pumping systems. Sol. Energy 2004, 76, 713-723. [CrossRef]

19. De Soto, W.; Klein, S.A.; Beckman, W.A. Improvement and validation of a model for photovoltaic array performance. Sol. Energy 2006, 80, 78-88. [CrossRef]

20. Sera, D.; Teodorescu, R.; Rodriguez, P. PV panel model based on datasheet values. In Proceedings of the IEEE International Symposium on Industrial Electronics (ISIE), Vigo, Spain, 4-7 June 2007; pp. 2392-2396.

21. Villalva, M.G.; Gazoli, J.R.; Filho, E.R. Comprehensive approach to modeling and simulation of photovoltaic arrays. IEEE Trans. Power Electron. 2009, 24, 1198-1208. [CrossRef]

22. Coelho, R.F.; Cancer, F.; Martins, D.C. A proposed photovoltaic module and array mathematical modeling destined to simulation. In Proceedings of the IEEE International Symposium on Industrial Electronics (ISIE), Seoul, Korea, 5-8 July 2009; pp. 1624-1629.

23. Lo Brano, V.; Orioli, A.; Ciulla, G.; Di Gangi, A. An improved five-parameter model for photovoltaic modules. Sol. Energy Mater. Sol. Cells 2010, 94, 1358-1370. [CrossRef]

24. Kim, W.; Choi, W. A novel parameter extraction method for the one-diode solar cell model. Sol. Energy 2010, 84, 1008-1019. [CrossRef]

25. Farivar, G.; Asaei, B. Photovoltaic module single diode model parameters extraction based on manufacturer datasheet parameters. In Proceedings of the IEEE International Conference on Power and Energy (PECon), Lumpur, Malaysia, 29 November-1 December 2010; pp. 929-934.

26. Carrero, C.; Ramírez, D.; Rodríguez, J.; Platero, C.A. Accurate and fast convergence method for parameter estimation of PV generators based on three main points of the I-V curve. Renew. Energy 2011, 36, 2972-2977. [CrossRef]

27. Chatterjee, A.; Keyhani, A.; Kapoor, D. Identification of photovoltaic source models. IEEE Trans. Energy Convers. 2011, 26, 883-889. [CrossRef]

28. Farret, F.A.; Lenz, J.M.; Trapp, J.G. New methodology to determinate photovoltaic parameters of solar panels. In Proceedings of the Brazilian Power Electronics Conference (COBEP), Natal, Brazil, 11-15 September 2011; pp. 275-279.

29. Seddaoui, N.; Rahmani, L.; Kessal, A.; Chauder, A. Parameters extraction of photovoltaic module at reference and real conditions. In Proceedings of the 46th International Universities' Power Engineering Conference (UPEC), Soest, Germany, 5-8 September 2011; pp. 1-6.

30. Katsanevakis, M. Modelling the photovoltaic module. In Proceedings of the IEEE International Symposium on Industrial Electronics (ISIE), Gdansk, Poland, 27-30 June 2011; pp. 1414-1419.

31. Lo Brano, V.; Orioli, A.; Ciulla, G. On the experimental validation of an improved five-parameter model for silicon photovoltaic modules. Sol. Energy Mater. Sol. Cells 2012, 105, 27-39. [CrossRef] 
32. Lineykin, S.; Averbukh, M.; Kuperman, A. A five-parameter model of photovoltaic cell based on STC data and dimensioneless. In Proceedings of the IEEE 27th Convention of Electrical \& Electronics Engineers in Israel (IEEEI), Eilat, Israel, 14-17 November 2012; pp. 1-5.

33. Can, H.; Ickilli, D.; Parlak, K.S. A new numerical solution approach for the real-time modeling of photovoltaic panels. In Proceedings of the 2012 Asia-Pacific Power and Energy Engineering Conference (APPEEC), Shanghai, China, 27-29 March 2012; pp. 1-4.

34. Ahmad, M.; Talukder, A.; Tanni, M.A. Estimation of important parameters of photovoltaic modules from manufacturer's datasheet. In Proceedings of the International Conference on Informatics, Electronics \& Vision (ICIEV), Dhaka, Bangladesh, 18-19 May 2012; pp. 571-576.

35. Mahmoud, S.A.; Mohamed, H.N. Novel modeling approach for photovoltaic arrays. In Proceedings of the IEEE 55th International Midwest Symposium on Circuits and Systems (MWSCAS), Boise, ID, USA, 5-8 August 2012; pp. 790-793.

36. Sangsawang, V.; Chaitusanel, S. Modeling of photovoltaic module from commercial specification in datasheet. In Proceedings of the 9th International Conference on Electrical Engineering/Electronics, Computer, Telecommunications and Information Technology (ECTI-CON), Phetchaburi, Thailand, 16-18 May 2012; pp. 1-4.

37. Tian, H.; Mancilla-David, F.; Ellis, K.; Muljadi, E.; Jenkins, P. A cell-to-module-to-array detailed model for photovoltaic panels. Sol. Energy 2012, 86, 2695-2706. [CrossRef]

38. Orioli, A.; Di Gangi, A. A procedure to calculate the five-parameter model of crystalline silicon photovoltaic modules on the basis of the tabular performance data. Appl. Energy 2013, 102, 1160-1177. [CrossRef]

39. Islam, M.A.; Merabet, A.; Beguenane, R.; Ibrahim, H. Modeling solar photovoltaic cell and simulated performance analysis of a $250 \mathrm{~W}$ PV module. In Proceedings of the IEEE Electrical Power \& Energy Conference (EPEC), Halifax, NS, Canada, 21-23 August 2013; pp. 1-6.

40. Jena, D.; Ramana, V.V. Simple and accurate method of modelling photovoltaic module: A different approach. In Proceedings of the International Conference on Green Computing, Communication and Conservation of Energy (ICGCE), Chennai, India, 12-14 December 2013; pp. 465-469.

41. Siddique, H.A.B.; Xu, P.; de Doncker, R.W. Parameter extraction algorithm for one-diode model of PV panels based on datasheet values. In Proceedings of the International Conference on Clean Electrical Power (ICCEP), Alghero, Italy, 11-13 June 2013; pp. 7-13.

42. Siddiqui, M.U.; Arif, A.F.M.; Bilton, A.M.; Dubowsky, S.; Elshafei, M. An improved electric circuit model for photovoltaic modules based on sensitivity analysis. Sol. Energy 2013, 90, 29-42. [CrossRef]

43. Tian, H.; Mancilla-David, F.; Muljadi, E.; Stoffel, T.; Andreas, A. Model validation of photovoltaic systems. In Proceedings of the IEEE Green Technologies Conference, Denver, CO, USA, 4-5 April 2013; pp. $93-97$.

44. Yetayew, T.T.; Jyothsna, T.R. Improved single-diode modeling approach for photovoltaic modules using data sheet. In Proceedings of the Annual IEEE India Conference (INDICON), Mumbai, India, 13-15 December 2013; pp. 1-6.

45. Bai, J.; Liu, S.; Hao, Y.; Zhang, Z.; Jiang, M.; Zhang, Y. Development of a new compound method to extract the five parameters of PV modules. Energy Convers. Manag. 2014, 79, 294-303. [CrossRef]

46. Cubas, J.; Pindado, S.; Victoria, M. On the analytical approach for modeling photovoltaic systems behaviour. J. Power Sources 2014, 247, 467-474. [CrossRef]

47. Lineykin, S.; Averbukh, M.; Kuperman, A. An improved approach to extract the single-diode equivalent circuit parameters of a photovoltaic cell/panel. Renew. Sustain. Energy Rev. 2014, 30, 282-289. [CrossRef]

48. Ma, T.; Yang, H.; Lu, L. Development of a model to simulate the performance characteristics of crystalline silicon photovoltaic modules/strings/arrays. Sol. Energy 2014, 100, 31-41. [CrossRef]

49. Xu, Y.; Kong, X.; Zeng, Y.; Tao, S.; Xiao, X. A modeling method for photovoltaic cells using explicit equations and optimization algorithm. Electr. Power Energy Syst. 2014, 59, 23-28. [CrossRef]

50. Jervase, J.A.; Bourdoucen, H.; Al-Lawati, A. Solar cell parameter extraction using genetic algorithms. Meas. Sci. Technol. 2001, 12, 1922-1925. [CrossRef]

51. Jain, A.; Kapoor, A. Exact analytical solutions of the parameters of real solar cells using Lambert W-function. Sol. Energy Mater. Sol. Cells 2004, 81, 269-277. [CrossRef]

52. Ortiz-Conde, A.; García Sanchez, F.J.; Muci, J. New method to extract the model parameters of solar cells from the explicit analytic solutions of their illuminated I-V characteristics. Sol. Energy Mater. Sol. Cells 2006, 90, 352-361. [CrossRef] 
53. Mekki, H.; Mellit, A.; Salhi, H.; Khaled, B. Modeling and simulation of photovoltaic panel based on artificial neural networks and VHDL-language. In Proceedings of the 14th IEEE International Conference on Electronics, Circuits and Systems (ICECS), Marrakech, Morocco, 11-14 December 2007; pp. 58-61.

54. Moldovan, N.; Picos, R.; Garcia-Moreno, E. Parameter extraction of a solar cell compact model using genetic algorithms. In Proceedings of the Spanish Conference on Electron Devices (CDE), Santiago De Compostela, Spain, 11-13 February 2009; pp. 379-382.

55. Zagrouba, M.; Sellami, A.; Bouaïcha, M.; Ksouri, M. Identification of PV solar cells and modules parameters using the genetic algorithms: Application to maximum power extraction. Sol. Energy 2010, 84, 860-866.

56. Sandrolini, L.; Artioli, M.; Reggiani, U. Numerical method for the extraction of photovoltaic module double-diode model parameters through cluster analysis. Appl. Energy 2010, 87, 442-451. [CrossRef]

57. Ishaque, K.; Salam, Z.; Taheri, H.; Shamsudin, A. A critical evaluation of EA computational methods for photovoltaic cell parameter extraction based on two-diode. Sol. Energy 2011, 85, 1768-1779. [CrossRef]

58. Ishaque, K.; Salam, Z. An improved modelling method to determine the model parameters of photovoltaic (PV) modules using differential evolution (DE). Sol. Energy 2011, 85, 2349-2359. [CrossRef]

59. Askarzadeh, A.; Rezazadeh, A. Parameter identification for solar cell models using harmony search-based algorithms. Sol. Energy 2012, 84, 3241-3249. [CrossRef]

60. Toledo, F.J.; Blanes, J.M.; Garrigós, A.; Martínez, J.A. Analytical resolution of the electrical four-parameters model of a photovoltaic module using small perturbation around the operating point. Renew. Energy 2012, 43, 83-89. [CrossRef]

61. Lun, S.; Du, C.; Yang, G.; Wang, S.; Guo, T.; Sang, J.; Li, J. An explicit approximate I-V characteristic model of a solar cell based on padé approximants. Sol. Energy 2013, 92, 147-159. [CrossRef]

62. Laudani, A.; Riganti Fulginei, F.; Salvini, A. High performing extraction procedure for the one-diode modelof a photovoltaic panel from experimental $I-V$ curves by using reduced forms. Sol. Energy 2014, 103, 316-326. [CrossRef]

63. Laudani, A.; Riganti Fulginei, F.; Salvini, A. Identification of the one-diode model for photovoltaic modules from datasheet values. Sol. Energy 2014, 108, 432-446. [CrossRef]

64. Townsend, T.U. A Method for Estimating the Long-Term Performance of Direct-Coupled Photovoltaic Systems. Master's Thesis, Mechanical Engineering, University of Wisconsin-Madison, Madison, WI, USA, 1989.

65. Duffie, J.A.; Beckman, W.A. Solar Engineering of Thermal Processes, 2nd ed.; Wiley Interscience: New York, NY, USA, 1991.

66. Xiao, W.; Dunford, W.G.; Capel, A. A novel modeling method for photovoltaic cells. In Proceedings of the IEEE 35th Annual Power Electronics Specialists Conference (PESC 04), Aachen, Germany, $20-25$ June 2004; pp. 1950-1956.

67. Ulapane, N.N.B.; Dhanapala, C.H.; Wickramasinghe, S.M.; Abeyratne, S.G.; Rathnayake, N.; Binduhewa, P.J. Extraction of parameters for simulating photovoltaic panels. In Proceedings of the 6th IEEE International Conference on Industrial and Information Systems (ICIIS), Kandy, Sri Lanka, 16-19 August 2011; pp. 539-544.

68. Saloux, E.; Teyssedou, A.; Sorin, M. Explicit model of photovoltaic panels to determine voltages and currents at the maximum power point. Sol. Energy 2011, 85, 713-722. [CrossRef]

69. Mahmoud, Y.; Xiao, W.; Zeineldin, H.H. A simple approach to modeling and simulation of photovoltaic modules. IEEE Trans. Sustain. Energy 2012, 3, 185-186. [CrossRef]

70. Mahmoud, Y.; Xiao, W.; Zeineldin, H.H. A parameterization approach for enhancing PV model accuracy. IEEE Trans. Ind. Electron. 2013, 60, 5708-5716. [CrossRef]

71. Cristaldi, L.; Faifer, M.; Rossi, M.; Toscani, S. A simplified model of photovoltaic panel. In Proceedings of the IEEE International Instrumentation and Measurement Technology Conference (I2MTC), Graz, Austria, 13-16 May 2012; pp. 431-436.

72. Averbukh, M.; Lineykin, S.; Kuperman, A. Obtaining small photovoltaic array operational curves for arbitrary cell temperatures and solar irradiation densities from standard conditions data. Prog. Photovolt. Res. Appl. 2013, 21, 1016-1024. [CrossRef]

73. Chenni, R.; Makhlouf, M.; Kerbache, T.; Bouzid, A. A detailed modeling method for photovoltaic cells. Energy 2007, 32, 1724-1730. [CrossRef]

74. Eckstein, J.H. Detailed Modeling of Photovoltaic Components. Master's Thesis, Solar Energy Laboratory, University of Wisconsin, Madison, WI, USA, 1990. 
75. Kou, Q.; Klein, S.A.; Beckman, W.A. A method for estimating the long-term performance of direct-coupled PV pumping system. Sol. Energy 1998, 64, 33-40. [CrossRef]

76. Celik, A.N.; Acikgoz, N. Modelling and experimental verification of the operating current of mono-crystalline photovoltaic modules using four- and five-parameter models. Appl. Energy 2007, 84, 1-15. [CrossRef]

77. Chenlo, F.; Fabero, F.; Alonso, M.C. A Comparative Study between Indoor and Outdoor Measurements; Final Report of Project: Testing, Norms, Reliability and Harmonisation. Joule II-Contract No. JOU2-CT92-0178; European Commission: Brussels, Belgium, 1995.

(c) 2016 by the authors; licensee MDPI, Basel, Switzerland. This article is an open access article distributed under the terms and conditions of the Creative Commons Attribution (CC-BY) license (http://creativecommons.org/licenses/by/4.0/). 